\title{
Characteristics of pollutants and their correlation to meteorological conditions at a suburban site in the North China Plain
}

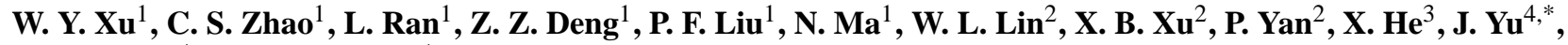 \\ W. D. Liang ${ }^{4}$, and L. L. Chen ${ }^{4}$ \\ ${ }^{1}$ Department of Atmospheric and Oceanic Sciences, School of Physics, Peking University, Beijing, China \\ ${ }^{2}$ Key Laboratory for Atmospheric Chemistry, Centre for Atmosphere Watch and Services, Chinese Academy of \\ Meteorological Sciences, China Meteorological Administration, Beijing, China \\ ${ }^{3}$ Aviation Meteorological Center, Air Traffic Management Bureau, Civil Aviation Administration of China, Beijing, China \\ ${ }^{4}$ Wuqing Meteorological Bureau of Tianjin, China \\ *now at: Tanggu Meteorological Bureau of Tianjin, China
}

Received: 11 December 2010 - Published in Atmos. Chem. Phys. Discuss.: 2 March 2011

Revised: 29 April 2011 - Accepted: 2 May 2011 - Published: 11 May 2011

\begin{abstract}
North China Plain (NCP) is one of the most densely populated regions in China and has experienced enormous economic growth in the past decades. Its regional trace gas pollution has also become one of the top environmental concerns in China. Measurements of surface trace gases, including $\mathrm{O}_{3}, \mathrm{NO}_{\mathrm{x}}, \mathrm{SO}_{2}$ and $\mathrm{CO}$ were carried out within the HaChi (Haze in China) project at Wuqing Meteorology Station, located between 2 mega-cities (Beijing and Tianjin) in the NCP, from 9 July 2009 to 21 January 2010. Detailed statistical analyses were made in order to provide information on the levels of the measured air pollutants and their characteristics. Gaseous air pollutant concentrations were also studied together with meteorological data and satellite data to help us better understand the causes of the observed variations in the trace gases during the field campaign. In comparison to measurements from other rural and background stations in the NCP, relatively high concentrations were detected in Wuqing, presumably due to regional mixing and transport of pollutants. Local meteorology had deterministic impacts on air pollution levels, which have to be accounted for when evaluating other effects on pollutant concentrations. Trace gas concentrations showed strong dependence on wind, providing information on regional pollution characteristics. $\mathrm{O}_{3}$ mixing ratio also showed clear dependencies on temperature and relative humidity.
\end{abstract}

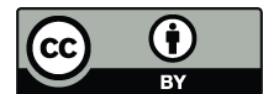

Correspondence to: C. S. Zhao

(zcs@pku.edu.cn)

\section{Introduction}

Economic reforms since 1978 have brought rapid developments for China. With them came increased emissions of air pollutants, environmental problems and health concerns, caused by industries, power plants, vehicles and other needs for combustion of fuel (Kan and Chen, 2004; Hao and Wang, 2005; Shao et al., 2006).

Carbon monoxide $(\mathrm{CO})$, nitrogen oxides $\left(\mathrm{NO}_{\mathrm{x}}\right)$ and sulphur dioxide $\left(\mathrm{SO}_{2}\right)$ are all trace gases in the atmosphere and primary pollutants emitted from anthropogenic activities (Kato and Akimoto, 1994; Streets and Waldhoff, 2000). Emitted mainly by combustion sources and having relatively longer atmospheric lifetime, $\mathrm{CO}$ is also an ideal tracer for anthropogenic pollution, facilitating the interpretation of the concentrations of other pollutants (Parrish et al., 1993, 1998; Wang et al., 1996, 1997; Jaffe et al., 1997). $\mathrm{NO}_{\mathrm{x}}$, however, has a very short lifetime and is mainly emitted through fossil fuel burning. Additionally, $\mathrm{CO}$ and $\mathrm{NO}_{\mathrm{x}}$ are precursors of ozone $\left(\mathrm{O}_{3}\right)$, which is the most important secondary pollutant in the atmosphere (Jenkin et al., 2000). $\mathrm{O}_{3}$ is a major component of photochemical smog, and can be hazardous to vegetation, materials and human health (PORG, 1997). $\mathrm{SO}_{2}$ is also an important trace gas. Its oxidation can lead to acid deposition and also contributes to the formation of sulphate aerosols (Meagher et al., 1978; Saxena and Seigneur, 1987), which in turn will have impacts on the solar radiation and photochemistry (Dickerson et al., 1997). $\mathrm{SO}_{2}$ levels are typically very high, especially in North China, where domestic heating during winter largely relies on coal combustion.

Published by Copernicus Publications on behalf of the European Geosciences Union. 
Mega-cities in China commonly suffer from severe air pollution (Ran et al., 2009; Liu et al., 2009). Neighbouring regions, especially downwind regions, are typically enveloped by regional pollution. One of the most severely polluted areas in the world is the North China Plain (NCP) region (van Donkelaar et al., 2010), in which there are two of the most heavily populated mega-cities in China, Beijing and Tianjin. Concerns were raised during preparation for the 2008 Summer Olympic Games in Beijing and numerous studies have been done since then (e.g., Xu et al., 2005; Ding et al., 2008; Lin et al., 2008, 2009; Wang et al., 2009). It was found that, since winter 2007, there were improvements in the overall combustion efficiency (Wang et al., 2010). Chan et al. (2008) reported decreasing trends for the concentrations of $\mathrm{SO}_{2}$ (from $120 \mu \mathrm{g} \mathrm{m}^{-3}$ to $50 \mu \mathrm{g} \mathrm{m}^{-3}$ ) and $\mathrm{CO}$ (from $3.3 \mathrm{mg} \mathrm{m}^{-3}$ to $2.0 \mathrm{mg} \mathrm{m}^{-3}$ ) in Beijing for the period of 1998 to 2005 , while $\mathrm{NO}_{2}$ emissions did not vary. Nevertheless, pollution events still often occurred in urban and surrounding areas. For example, a maximum 1-h $\mathrm{O}_{3}$ mixing ratio of $286 \mathrm{ppbv}$ was reported in a mountainous area north of Beijing and attributed to a polluted plume from urban Beijing (Wang et al., 2006). Such pollution episodes are commonly caused by both the emissions of primary pollutants and the accompanied weather conditions.

Regional and local scale meteorology influences pollution in different ways. Large scale weather patterns determine atmospheric stability, large scale circulations, temperature advection, humidity and cloud formation, which all have great impacts on the mixing scale of various pollutants and the formation of secondary air pollutants. Recent research reveals that synoptic pressure patterns and their evolution are the main causes of regional air pollution processes in the NCP (Chen et al., 2008). High pressure and successive low pressure systems were associated with the formation of air pollution, and pressure systems with strong gradients led to decreases of the Air Pollution Index (API). Modelling studies also confirmed that summertime high pressure systems can turn the East China Plains into a "basin" of ozone pollution (Zhao et al., 2009). Since emissions are almost constant during a given season, it is the meteorological pattern that determines whether heavy pollution can form on a regional scale. Local meteorological parameters are not always consistent with those on a larger scale, but they also have substantial influence on air pollution. In fact, there are several local meteorological factors that can affect both regional and local concentrations of pollutants. Wind speed can alter the dispersion state of the atmosphere (Prosmitis et al., 2003; Ulas et al., 2006; Jones et al., 2010), while wind directions provide information on the transport of pollutants (Lin et al., 2008). In regard to chemical reactions and transformations, temperature, solar radiation and humidity conditions are the most crucial factors (Korsog and Wolff, 1991; Greene et al., 1999). However, no clear linear relationships could be found between meteorological parameters (i.e., wind speed, ultraviolet radiation, or temperature) and the concentration of pol- lutants (Liu et al., 1994). Moreover, vertical distribution of pollutants can be modified by local circulations (Chen et al., 2009). Thus, it becomes highly necessary for setting up air quality management strategies, to know the relationships between meteorological factors and trace gases concentrations.

In recent years, in-situ measurements of atmospheric trace gas pollutants in the NCP were mostly made at rural sites (Gao et al., 2005; Lin et al., 2008, 2009; Wang et al., 2006, 2008) or in central Beijing (Tang et al., 2009). Few observations were made in between the city clusters. The interactions between the metropolitan areas are still unknown. For this study, we set up an observation site at a suburban site in between Beijing and Tianjin, designed to acquire more information on regional transport of pollutants between the two mega-cities by analysing the relationship between meteorological parameters (i.e. wind speed, wind direction, temperature, humidity, etc.) and local pollutant concentrations.

\section{Data and methodology}

\subsection{Site}

The measurements were done at the Wuqing Meteorological Station $\left(39^{\circ} 22^{\prime} 58.8^{\prime \prime} \mathrm{N} 117^{\circ} 1^{\prime} 1.2^{\prime \prime} \mathrm{E}, 7.4 \mathrm{~m}\right.$ a.s.l.). Wuqing is a suburban district, situated in between Beijing and Tianjin, the two heavily populated megacity centres (about $80 \mathrm{~km}$ to Beijing and $30 \mathrm{~km}$ to Tianjin) and surrounded by Hebei Province, as shown in Fig. 1. The Wuqing Meteorological Station is located east of large areas of farm fields, west of groups of small factories and northwest of the centre of Wuqing district, Tianjin. Further down to the southeast of Wuqing is the industrial zone of Tianjin, called Tianjin Binhai Industrial Area, and the city of Beijing is to the northwestern side. Traffic flow near the site is on a very low level, compared to the centres of metropolitans, and there are no large emission sources in the surrounding areas nearby. Unlike rural sites that are situated to the north of Beijing, such as Shangdianzi (SDZ) GAW station or Miyun Observation Site, Wuqing lies inside the polluted region, but is relatively clean, compared to the neighbouring mega-cities. Thus all the above mentioned criteria make Wuqing highly representative of the overall pollution level of the polluted NCP region and a favourable spot for observing transport of air pollutants.

\subsection{Trace gas measurements}

A set of commercial trace gas instruments (Thermo Environmental Instruments Inc., USA C-series) has been used to continuously monitor various trace gases. Surface $\mathrm{O}_{3}$ was measured with a UV photometric analyser (TE 49C), CO with a gas filter correlation analyser (TE $48 \mathrm{C}$ ), $\mathrm{NO}_{\mathrm{x}}$ with a chemiluminescence analyser (TE 42CTL) and $\mathrm{SO}_{2}$ with a pulsed UV fluorescence analyser (TE 43CTL), from 9 July 2009 to 21 January 2010. All the instruments were housed in 


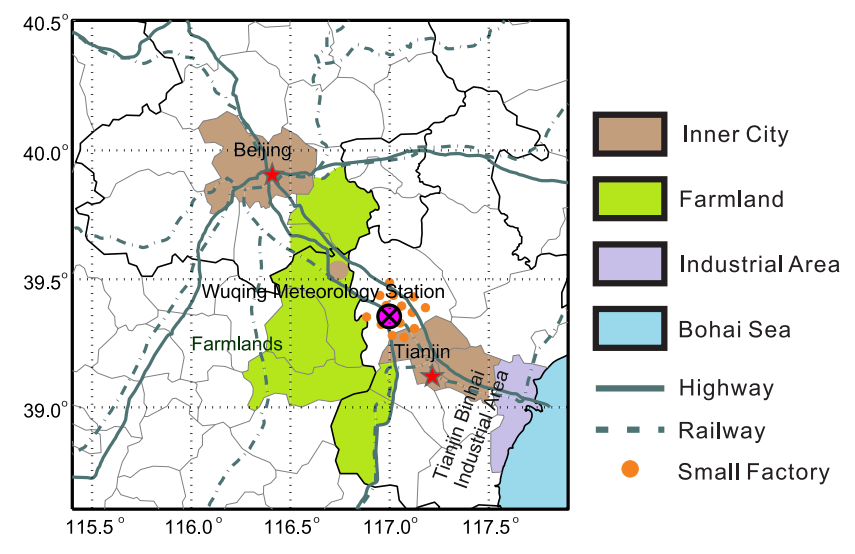

Fig. 1. Location of the campaign site (Wuqing Meteorology Station).

an air-conditioned container, with a relatively constant temperature. For $\mathrm{CO}$, zero checks are automatically executed every $6 \mathrm{~h}$; for the other primary gases, multipoint calibrations and daily zero/span checks were performed according to USEPA recommendations on quality assurance and quality control, using a dynamic gas calibrator (TE 146C) in combination with a zero air supplier (TE111) and a set of standard reference gas mixtures (National Institute of Metrology, Beijing, China). The $\mathrm{O}_{3}$ analyser was calibrated respectively in the beginning and at the end of the observation, using an $\mathrm{O}_{3}$ calibrator (TE 49CPS). Results suggest that the linear drift during the observation period was less than $0.5 \%$ and could be ignored.

Measured ambient concentrations were recorded as 1-min average mixing ratios by volume (ppbv). When analysing the statistical variability, diurnal cycle of trace gases and temperature/relative humidity(RH) dependency of ozone, 1-h averaged data were used; while for the calculations of trace gas wind dependency, 1-h moving averaged gas concentrations were employed to equalizing the sampling frequency.

\subsection{Determination of trace gas exceedance and High Pollution Days (HPD)}

To evaluate the overall pollution level at Wuqing, an exceedance standard was set up as the average trace gas level plus one standard deviation. For $\mathrm{O}_{3}$, the exceedance level was calculated using only the data before the 1 October 2009 , while for the primary gas pollutants, only the data after that date were used in the determination of the exceedance standard. Calculated exceedance standards for $\mathrm{CO}, \mathrm{NO}, \mathrm{NO}_{2}$, $\mathrm{NO}_{\mathrm{x}}, \mathrm{SO}_{2}$ and $\mathrm{O}_{3}$ were respectively $3878,80,52,43,128$ and $68 \mathrm{ppbv}$. The hours with 1 -h averaged measurements exceeding the defined standard were defined as exceedance hours, when total daily exceedance hours reached over $3 \mathrm{~h}$, the day was determined as a High Pollution Day (HPD) in respect to the exceeding trace gas. Monthly exceedance hour frequency is obtained by dividing the monthly total exceedance hours by the number of hours with valid measurements. Similarly HPD frequency is the ratio of monthly total HPDs to the number of days with valid measurements. Monthly Mean Exceedance Amount (MEA) was calculated as:

$\mathrm{MEA}=\frac{1}{h_{\text {Exceedance }}} \sum\left(m_{\text {Exceedance }}-m_{\text {Standard }}\right)$,

Where $m_{\text {Exeedance }}$ is the measured 1-h mean mixing ratio within a certain month that exceeded the above defined standard ( $\left.m_{\text {Standard }}\right)$, and $h_{\text {Exceedance }}$ is the monthly total number of exceedance hours.

\subsection{Meteorological data}

Meteorological variables were obtained by an Automatic Weather Station installed at the Wuqing Meteorological Station. Wind parameters are observed at $10 \mathrm{~m}$ height, while temperature, pressure and moisture information are collected at $1.5 \mathrm{~m}$ height. The moving averages of wind speed and wind direction were calculated over a span of $2 \mathrm{~h}$, since fluctuations in wind directions are less representative of transports from those directions. Average wind speed is calculated both using arithmetic and vector mean methods. The arithmetic mean wind speed WSa is greater than the vector mean WSv. The more consistent the wind direction, the more WSv tends towards WSa. Thus when analysing the wind dependency of various pollutants, only the data with relatively continuous wind directions will be considered, using a criterion of WSv/WSa $>0.95$. 2-h moving averaged wind data were used for the wind frequency rose, without taking into account the continuity of wind directions. Wind directions in this work are referred to as the directions the winds are coming from. NCEP FNL (Final) Operational Global Analysis data from 9 July 2009 to 21 January 2010 were used to supplement the analysis of regional weather patterns.

\subsection{Evaluation of trace gas wind dependency}

To determine the effect of wind speed and wind direction on various trace gas concentrations, two methods have been applied. In the first method, wind speed and wind direction are divided into bins of $0.5 \mathrm{~m} \mathrm{~s}^{-1} \times 10^{\circ}$. Trace gas concentrations (60-min moving averaged) are sorted into those bins, with the aid of simultaneous meteorological data. Samples in each bin were averaged and plotted on wind dependence maps, to display the overall variations of trace gas levels in different wind directions and with varying wind speeds. To avoid the influence of seasonal variations, wind dependence maps are separately drawn for different seasons.

The above method still only provides information on the average variation. Data in each bin may show large variability, due to other factors that also influence the pollutant concentrations. To be able to quantify the degree of influence, a 
second method is applied. Similar to the above, 60-min moving averaged gas pollutant concentrations were first divided according to seasons into 3 parts, respectively representing summer (15 July-31 August 2009), fall (1 September-30 November 2009) and winter (1 December 2009-21 January 2010). Then for each season, the 25th and 75th percentiles of the given gas species were calculated. Trace gas concentrations below the 25th percentile value are defined as "relatively clean" and concentrations above the 75th percentile value as "relatively polluted". According to different wind speed and direction, data are ordered into bins, this time with a resolution of $1 \mathrm{~m} \mathrm{~s}^{-1} \times 45^{\circ}$. In each bin two frequencies are calculated as follows:

$f_{75}$ (Gas, Season, WS, WD)

$=\frac{n\left([\mathrm{Gas}]_{\mathrm{iSeason}, \mathrm{iWS}, \mathrm{iWD}}>75 \text { percentile }[\mathrm{Gas}]_{\mathrm{iSeason}}\right)}{n\left([\mathrm{Gas}]_{\mathrm{iSeason}, \mathrm{iWS}, \mathrm{iWD}}\right)}$

$f_{25}$ (Gas, Season, WS, WD)

$=\frac{n\left([\mathrm{Gas}]_{\mathrm{iSeason}, \mathrm{iWS}, \mathrm{iWD}}<25 \text { percentile }[\mathrm{Gas}]_{\mathrm{iSeason}}\right)}{n\left([\mathrm{Gas}]_{\mathrm{i} \text { Season, iWS, iWD }}\right)}$,

where iSeason=summer, fall, winter; $\mathrm{iWS}=0-1,1-2, \ldots$, $12-13 \mathrm{~m} \mathrm{~s}^{-1} ; \mathrm{iWD}=\mathrm{S}, \mathrm{SW}, \mathrm{W}, \mathrm{NW}, \mathrm{N}, \mathrm{NE}, \mathrm{E}, \mathrm{SE}$; $n$ (condition) is the number of data samples fulfilling the conditions given in the parentheses. Calculations were performed for $\mathrm{CO}, \mathrm{SO}_{2}, \mathrm{NO}_{\mathrm{x}}, \mathrm{O}_{3}$.

$f_{75}$ reflects the ratio of data in a given bin that exceeds the overall 75th percentile gas concentration in a certain season, representing a probability of occurrence of the "relatively polluted" state under a particular wind direction and wind speed. Similarly, $f_{25}$ can be interpreted as the probability of the "relatively clean" state to occur under given wind direction and wind speed.

To quantify how much each wind direction contributes to the concentration level of various trace gases, it is inaccurate to simply subtract the average concentrations of all the bins by a background concentration, due to large standard deviations on both sides. But with the result of the second method, we can determine by how much a certain wind direction and wind speed increases the occurrence probability of the "relatively polluted" state. As it will be shown in Sect. 3.5.1, winds from the north show the lowest frequency of polluted conditions, thus is determined as a background. The frequency increment (or probability increment) of the "relatively polluted" state is calculated as:

$$
\begin{aligned}
\Delta f_{75} & =f_{75}(\mathrm{iGas}, \text { iSeason, iWS, iWD }) \\
& -f_{75}(\mathrm{iGas}, \text { iSeason, iWS }, N),
\end{aligned}
$$

representing how much a certain wind direction and wind speed increases or decreases the occurrence frequency of polluted conditions.

\subsection{Satellite data}

Four satellite datasets were used provide a view of the regional distribution of pollutants in the NCP region. Measurements of Pollution in the Troposphere (MOPITT), Ozone Measuring Instrument (OMI) and Moderate Resolution Imaging Spectroradiometer (MODIS) are instruments mounted on NASA's EOS Terra spacecraft. The MODIS instrument is also operating on NASA's EOS Aqua Spacecraft. MOPITT is designed to measure global distributions of carbon monoxide $(\mathrm{CO})$ in the troposphere, providing data once a day. Horizontal resolutions can reach up to $22 \mathrm{~km}$, vertical resolution up to $3 \mathrm{~km}$. Level 2 Version $4 \mathrm{CO}$ surface mixing ratio data of 1 March 2009 to 28 February 2010 were averaged into $0.25^{\circ} \times 0.25^{\circ}$ grids in this study. From OMI, $\mathrm{NO}_{2}$ and $\mathrm{SO}_{2}$ columns can be retrieved, with nadir view point reaching the resolution of $13 \times 24 \mathrm{~km}$. The OMI instrument has several cross-track anomalies, which were ruled out for both datasets. Level 2 OMI NO2 tropospheric column of the period mentioned above was interpolated and averaged into $0.25^{\circ} \times 0.25^{\circ}$ grids. Due to reduced OMI sensitivity to $\mathrm{SO}_{2}$ in the Planetary Boundary Layer (PBL), Level $2 \mathrm{OMI} \mathrm{SO}_{2}$ PBL column amount product can be used only under optimal viewing conditions, which require radiative cloud fraction $<0.2$, solar zenith angle $<40^{\circ}$ and near-nadir viewing angles (OMSO2Readme file). After accounting for those conditions, only data from summertime 2009 were left to be interpolated and averaged into $0.5^{\circ} \times 0.5^{\circ}$ grids. Aerosol Optical Depth (AOD) at $550 \mathrm{~nm}$ with best quality data is obtained from MODIS Aerosol product [MOD04 and MYD04 (http:// modis-atmos.gsfc.nasa.gov/MOD04_L2/index.html)]. AOD is interpolated into $0.1^{\circ} \times 0.1^{\circ}$ grids and data over the Bohai Sea were excluded due to poor data quality over offshore sea areas (Li et al., 2003).

\section{Results and discussion}

\subsection{Meteorology overview}

Wuqing is situated in the northern part of the NCP region. In the summer season, the West Pacific Subtropical High (WPSH) pushes northward, often merging with the continental high in the NCP region (Fig. 2). Near surface, at the $1000 \mathrm{hPa}$ pressure level, the region is controlled by the southerly wind to the west of the high-pressure system. Judging from the average wind flow, marine air travels through Shandong and Hebei Province before arriving in Wuqing. The centre of the WPSH tilts with height to the South, thus with increasing altitude, wind direction gradually turns to South-West, West and finally North-West.

In fall, the WPSH retreats to the south, while a cold high pressure system is forming in the northern inland. Near surface level, Wuqing is to the east of the high-pressure centre; at higher elevations, Wuqing is situated behind the ridge and 

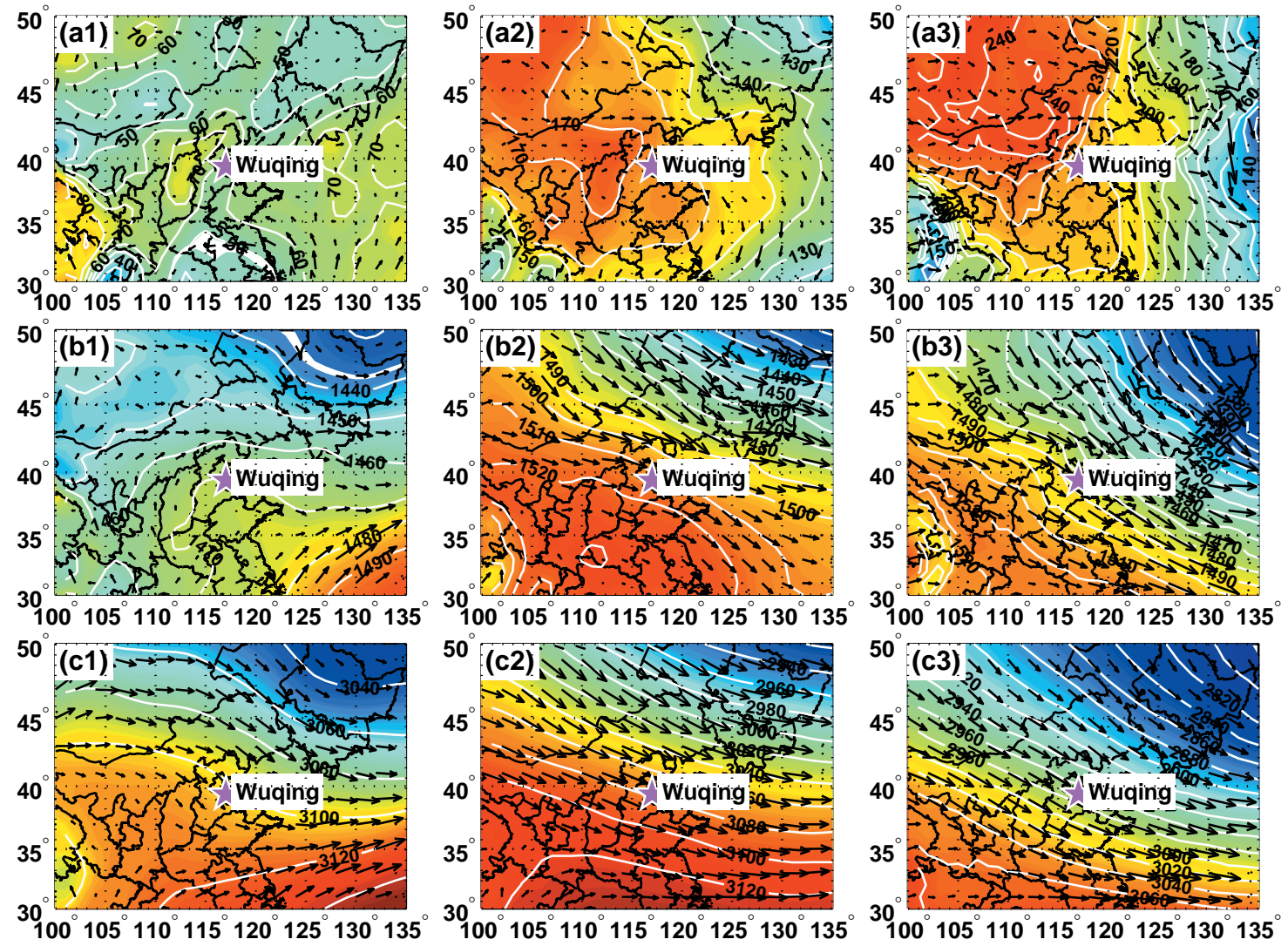

Fig. 2. Average Geopotential Height Field (white lines) and Wind Field (black vectors) for $1000 \mathrm{hPa}, 850 \mathrm{hPa}$ and $700 \mathrm{hPa}$ (indicated respectively by a, b, c) for summer (9 July 2009-31 August 2009), fall (1 September 2009-30 November 2009) and winter (1 December 2009-21 January 2009) (numbered as 1, 2, 3) from NCEP FNL (Final) Operational Global Analysis data. The magenta star marks the location of the observation site.

ahead of the trough, and thus the dominant wind direction in the NCP region turns with altitude from NNW to WNW.

In winter, the continental cold high-pressure system becomes stronger, and the WPSH is pushed further to the south onto the ocean; wind field is similar to that in fall, but the enhanced high-pressure system resulted in higher average wind speeds in the NCP region.

For the whole measurement period, the lowest surface pressure was accompanied by the highest surface temperature, which occurred in July, with a monthly mean of $1002.3 \mathrm{hPa}$ and $299.5 \mathrm{~K}$; while the highest monthly mean surface pressure, $1028.7 \mathrm{hPa}$, was observed along with the lowest mean surface temperature, $265.1 \mathrm{~K}$, in January. The monthly mean RH ranged from $59 \%$ to $77 \%$, with a maximum value in August and a minimum in January.

Figure 3 shows wind roses for summer, fall and winter. For each wind rose, the frequency of wind direction is given respectively for 4 wind speed ranges: $0-3 \mathrm{~m} \mathrm{~s}^{-1}, 3-6 \mathrm{~m} \mathrm{~s}^{-1}, 6-$ $9 \mathrm{~m} \mathrm{~s}^{-1},>9 \mathrm{~m} \mathrm{~s}^{-1}$, using the wind speed and direction data at $10 \mathrm{~m}$ height. In summer, SW wind dominates, especially for wind speeds between $3-6 \mathrm{~m} \mathrm{~s}^{-1}$; generally wind speed is low; occasional NW and SE wind may occur, but mostly with wind speed under $3 \mathrm{~m} \mathrm{~s}^{-1}$. SW wind still frequently occurs in fall when the wind speed is below $3 \mathrm{~m} \mathrm{~s}^{-1}$. Stronger winds mostly come from NNW, also now and then from the ENE direction. In winter, NNW winds with wind speed between 3-9 $\mathrm{m} \mathrm{s}^{-1}$ are dominant. Wind speeds above $9 \mathrm{~m} \mathrm{~s}^{-1}$ also occur under NNW directions, which are consistent with the synoptic wind field. Wind speeds below $3 \mathrm{~m} \mathrm{~s}^{-1}$ have relatively higher frequencies under $\mathrm{W}$ to $\mathrm{NW}$ and $\mathrm{NE}$ directions, but may also be of SW and SE directions from time to time.

\subsection{Distributions of pollutants in the NCP}

The NCP is a complex polluted region, consisting mainly of 2 mega-cities (Beijing and Tianjin) and Hebei Province, which encircles the two metropolitan areas. Though various pollutants show high values in the NCP region, they are regionally differently distributed. Figure 4a shows the annual (1 March 2009 to 1 March 2010) average $550 \mathrm{~nm}$ AOD distribution obtained from MODIS MOD04 and MYD04 dataset. Contour lines of considerably higher AOD values are closed around densely populated inner city areas of Beijing, Tianjin, 
(a)

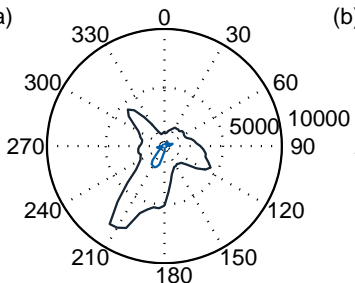

(b)

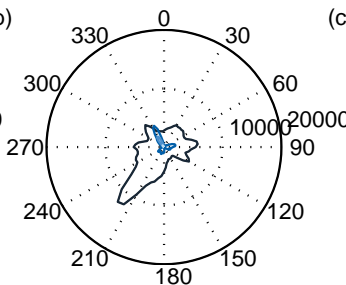

c)

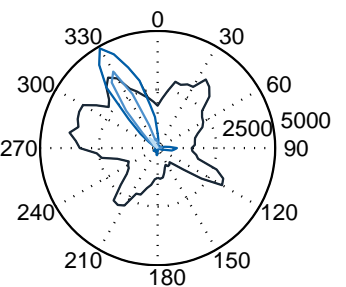

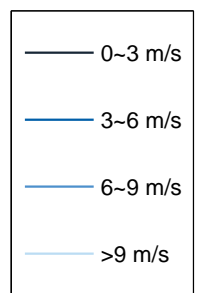

Fig. 3. Wind frequency rose for summer (9 July 2009-31 August 2009), fall (1 September 2009-30 November 2009) and winter (1 December 2009-21 January 2009).
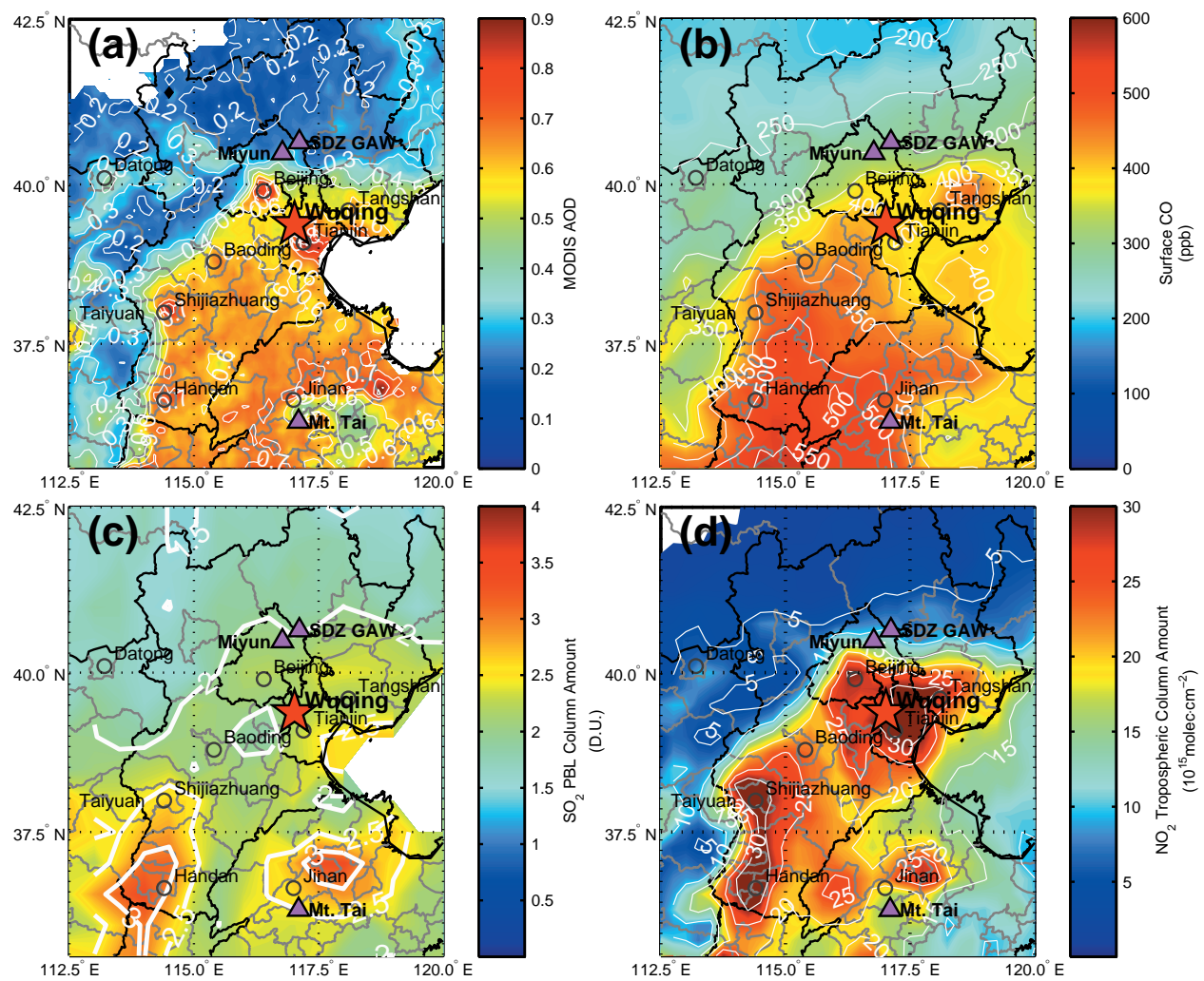

Fig. 4. 1 March 2009-1 March 2010 average distribution of (a) $550 \mathrm{~nm}$ AOD (MODIS L2, resolution: $0.1^{\circ} \times 0.1^{\circ}$ ); (b) CO Surface Mixing Ratio (MOPITT L2 Version 4, resolution: $0.25^{\circ} \times 0.25^{\circ}$ ); (c) $\mathrm{SO}_{2}$ Planetary Boundary Layer Column Amount (OMI L2, resolution: $\left.0.5^{\circ} \times 0.5^{\circ}\right)$; (d) $\mathrm{NO}_{2}$ Tropospheric Column Amount $\left(\mathrm{OMI}\right.$ L2, resolution: $\left.0.25^{\circ} \times 0.25^{\circ}\right)$ in NCP region.

Shijiazhuang, etc., suggesting severe anthropogenic aerosol pollution. Wuqing is situated between the high AOD centres of Beijing (0.80) and Tianjin (0.94), with a mean AOD of 0.65 , representing a suburban background state in the NCP region.

Carbon monoxide surface mixing ratio derived by MOPITT (Fig. 4b) reveals more severe CO pollution in the southern part of the NCP region. A clear high centre of $\mathrm{CO}$ to the ENE direction of Wuqing, where Tangshan is located, was also clearly noted. Interestingly, the belt from Beijing to Tianjin shows relatively lower CO concentrations, implying that traffic is not a major source to atmospheric $\mathrm{CO}$ over the NCP region.
Mean $\mathrm{SO}_{2}$ PBL column amount distribution from OMI mainly reflects summertime conditions, due to data filtering. As displayed in Fig. 4c, regional high concentrations are found to the east of Wuqing and two other high centres are respectively in the SW (Handan) and S (Northeast Jinan) direction. Column amounts in Beijing and Wuqing are at the regional background pollution level.

$\mathrm{NO}_{2}$ is short-lived, and therefore its tropospheric column provides insight into the emission sources. Although transportation plays only a secondary role in the emission of $\mathrm{NO}_{\mathrm{x}}$ in China (Zhang et al., 2009), Hao and Wang (2005) pointed out that in Beijing, $74 \%$ of ground $\mathrm{NO}_{\mathrm{x}}$ originates from vehicular emissions, while power plants and industrial 


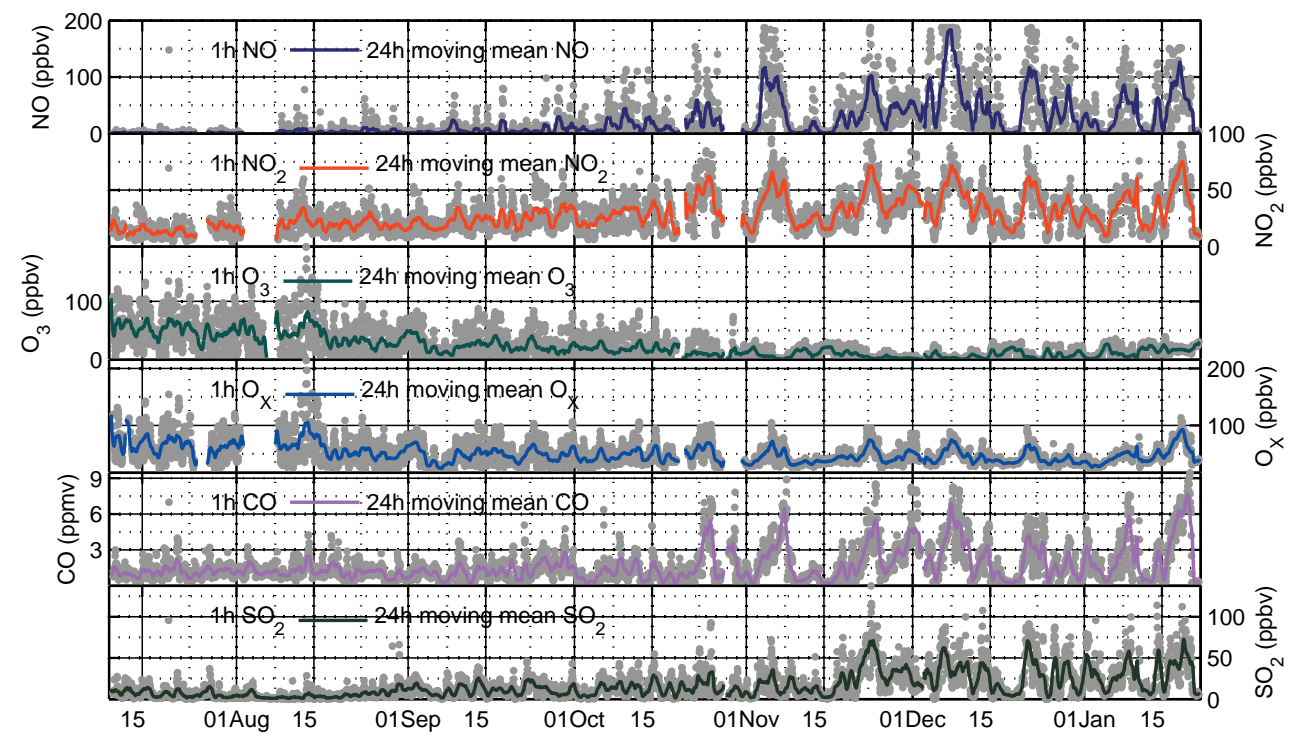

Fig. 5. 1-h average and 24-hour moving average $\mathrm{NO}, \mathrm{NO}_{2}, \mathrm{O}_{3}, \mathrm{O}_{\mathrm{x}}, \mathrm{CO}, \mathrm{SO}_{2}$ mixing ratio time series.

processes only contribute $15 \%$. The $\mathrm{NO}_{2}$ distribution, as shown in Fig. 4d, reveals strong local pollution in Beijing, Tianjin, Shijiazhuang and Handan; while Tianjin, which is closer to our site, seems to suffer more severe $\mathrm{NO}_{2}$ pollution than Beijing. Though Wuqing itself does not experience heavy traffic flows, it is surrounded by severe regional $\mathrm{NO}_{2}$ pollution, leading to locally higher concentrations, despite relatively low local emissions.

\subsection{Variability of $\mathrm{O}_{3}, \mathrm{NO}_{\mathrm{x}}, \mathrm{CO}$ and $\mathrm{SO}_{2}$}

24-h moving average time series and 1-h data of NO, $\mathrm{NO}_{2}$, $\mathrm{O}_{3}, \mathrm{O}_{\mathrm{x}}, \mathrm{CO}$ and $\mathrm{SO}_{2}$ mixing ratios are shown in Fig. 5. In general, $\mathrm{NO}_{\mathrm{x}}\left(\mathrm{NO}+\mathrm{NO}_{2}\right), \mathrm{CO}$ and $\mathrm{SO}_{2}$ concentration levels are lower during summer than in fall and winter, while for $\mathrm{O}_{3}$, concentrations are highest during summer, due to seasonal variations of photochemical $\mathrm{O}_{3}$ formation related to UV radiation, temperature, etc. There are several reasons behind such seasonal variations. First of all, the mixing layer height is generally lower in winter than that in summer. The shallower mixing layer is the principal contributor to the higher concentrations of primary emitted gaseous pollutants in winter. Secondly, domestic heating starts in the NCP region in November and ends in March. During this period, more combustion of coal leads to higher emissions of $\mathrm{SO}_{2}$, $\mathrm{NO}_{\mathrm{x}}$ and CO. Thirdly, photochemistry is most active during summer, accelerating the transformation of primary gaseous pollutants, whereas in winter, weaker photochemical reactions cannot remove the gases as quick as in the warmer seasons from the atmosphere. Another cause might be the meteorological pattern in winter, which often favours of accumulation of pollutants. As was shown in Fig. 2, the NCP region is often dominated by a cold high pressure system with low surface wind speeds, sometimes also accompanied by surface temperature inversion. Those conditions are favourable for the formation of haze or fog, and usually lead to high levels of $\mathrm{NO}_{\mathrm{x}}, \mathrm{CO}$ and $\mathrm{SO}_{2}$ due to weak diffusion. Hazy days appear frequently in the NCP region during winter season. Only when Wuqing is behind a trough and Siberian air moves southward accompanied by high wind speed, do regional pollutants get diluted or advected away.

A statistical analysis on the trace gas measurements and observations from other sites is summarized in Table 1. Mean daytime CO mixing ratio at Wuqing in JA (July and August) is $1.1 \mathrm{ppmv}$ (1100 ppbv), which is $500 \mathrm{ppbv}$ higher than the daytime mean CO level at Miyun $\left(40^{\circ} 29^{\prime} \mathrm{N}\right.$, $116^{\circ} 46.45^{\prime} \mathrm{E}, 152 \mathrm{~m}$ a.s.l.) in JJA 2006 (Wang et al., 2008). The all-day mean CO, $1.2 \mathrm{ppmv}$, is respectively 800 and $400 \mathrm{ppbv}$ higher than the CO level at Mt. Tai $\left(36^{\circ} 15^{\prime} \mathrm{N}\right.$, $117^{\circ} 06^{\prime} \mathrm{E}, 1534 \mathrm{~m}$ a.s.l) in JA 2003 (Gao et al., 2005) and $\operatorname{SDZ}\left(40^{\circ} 39^{\prime} \mathrm{N}, 117^{\circ} 07^{\prime} \mathrm{E}, 293.9 \mathrm{~m}\right.$ a.s.l.) in JA 2006 (Meng et al., 2009). In DJ (December and January), mean CO can reach $2.4 \pm 2.1$ ppmv, while monthly mean $\mathrm{CO}$ at SDZ during May 2005 to December 2006 did not exceed 900 ppbv. Seasonal mean $\mathrm{SO}_{2}$ concentrations in Wuqing range from $5.7 \pm 6.3$ (JA) to $28.5 \pm 6.3$ ppbv (DJ), while monthly mean $\mathrm{SO}_{2}$ at SDZ during 2003-2006 vary between 0.1-15.2 ppbv. $\mathrm{NO}_{\mathrm{x}}$ ranges from $20.4 \pm 12.2 \mathrm{ppbv}$ in JA to $80.8 \pm 65.5 \mathrm{ppbv}$ in $\mathrm{DJ}, \mathrm{NO}_{2}$ from $17.9 \pm 8.5$ to $35.1 \pm 18.2$ ppbv. $2004-$ 2006 July-January monthly mean $\mathrm{NO}_{2}$ at $\mathrm{SDZ}$ ranges from $5.2 \mathrm{ppbv}$ in July to $19.2 \mathrm{ppbv}$ in December (Lin et al., 2008). In contrast, Mt. Cimone, Italy station reported a mean $\mathrm{NO}_{\mathrm{x}}$ of $1.15 \pm 0.8 \mathrm{ppbv}$ for June 2000 (Fisher et al., 2003), which represents a continental background $\mathrm{NO}_{\mathrm{x}}$ level of Europe. It can be concluded that primary gas pollutant concentrations at our site are much higher than those reported from clean rural 
Table 1. Mean trace gas levels for different seasons and different time of day (using hourly averaged data) and comparisons with literature data.

\begin{tabular}{|c|c|c|c|c|c|c|c|c|c|c|c|}
\hline \multirow[t]{2}{*}{ Gases } & \multirow[t]{2}{*}{ Location } & \multirow[t]{2}{*}{ Time } & \multicolumn{3}{|c|}{ All-day } & \multicolumn{3}{|c|}{ Daytime (11:00-17:00) } & \multicolumn{3}{|c|}{ Night time $(23: 00-5: 00)$} \\
\hline & & & Mean & Std & Max & Mean & Std & Max & Mean & Std & $\operatorname{Max}$ \\
\hline \multirow[t]{7}{*}{$\mathrm{CO}(\mathrm{ppmv})$} & Wuqing & JA(2009) & 1.2 & 0.6 & 4.3 & 1.1 & 0.5 & 3.7 & 1.3 & 0.7 & 4.3 \\
\hline & Wuqing & SON(2009) & 1.5 & 1.4 & 8.9 & 1.3 & 1.4 & 8.2 & 1.5 & 1.3 & 7.8 \\
\hline & Wuqing & DJ(2009-2010) & 2.4 & 2.1 & 9.4 & 1.8 & 1.8 & 8.7 & 2.5 & 2.2 & 9.4 \\
\hline & Miyun & JJA $(2006)^{\mathrm{a}}$ & - & - & - & 0.6 & - & - & - & - & - \\
\hline & Mt. Tai & \multicolumn{10}{|c|}{ All-day mean(2003): JA: 0.42 ppbv, ON: 0.36 ppbv $^{\text {b }}$} \\
\hline & & $\mathrm{JA}(2006)^{\mathrm{b}}$ & $\sim 0.7$ & - & - & - & - & - & - & - & - \\
\hline & SDZ & Annual (2006) ${ }^{\mathrm{b}}$ & 0.74 & 0.56 & 3.9 & - & - & - & - & - & - \\
\hline \multirow[t]{4}{*}{$\mathrm{SO}_{2}(\mathrm{ppbv})$} & Wuqing & JA & 5.7 & 6.3 & 66.1 & 5.7 & 5.6 & 28.3 & 5.9 & 6.9 & 64.4 \\
\hline & Wuqing & SON & 15.7 & 15.4 & 137.7 & 18.6 & 20.0 & 137.7 & 13.7 & 12.6 & 76.5 \\
\hline & Wuqing & DJ & 28.5 & 22.8 & 114.2 & 30.3 & 26.7 & 112.4 & 26.0 & 21.3 & 114.2 \\
\hline & SDZ & \multicolumn{10}{|c|}{$\operatorname{Aug}(2003)-\operatorname{Dec}(2006)$ monthly mean: $0.1-15.2 \mathrm{ppbv}^{\mathrm{c}}$} \\
\hline \multirow[t]{4}{*}{$\mathrm{NO}_{2}(\mathrm{ppbv})$} & Wuqing & JA & 17.9 & 8.5 & 59.7 & 12.2 & 4.9 & 29.7 & 21.4 & 9.6 & 59.7 \\
\hline & Wuqing & SON & 30.1 & 15.8 & 95.1 & 25.5 & 17.9 & 95.1 & 30.0 & 12.4 & 63.2 \\
\hline & Wuqing & DJ & 35.1 & 18.2 & 90.4 & 30.9 & 20.0 & 89.2 & 35.3 & 16.2 & 71.6 \\
\hline & SDZ & \multicolumn{10}{|c|}{ 2004-2006 July-January monthly mean: 5.2-19.2 ppbv } \\
\hline \multirow[t]{3}{*}{$\mathrm{NO}_{\mathrm{X}}(\mathrm{ppbv})$} & Wuqing & JA & 20.4 & 12.2 & 113.5 & 13.3 & 5.6 & 36.9 & 23.4 & 13.0 & 96.4 \\
\hline & Wuqing & SON & 49.5 & 43.0 & 274.4 & 33.7 & 31.1 & 194.0 & 48.7 & 38.1 & 224.6 \\
\hline & Wuqing & DJ & 80.8 & 65.5 & 268.5 & 50.6 & 40.1 & 195.0 & 85.2 & 67.9 & 252.7 \\
\hline \multirow[t]{5}{*}{$\mathrm{O}_{3}(\mathrm{ppbv})$} & Wuqing & JA & 45.2 & 32.5 & 194.0 & 64.1 & 28.3 & 194.0 & 23.9 & 17.3 & 76.8 \\
\hline & Wuqing & SON & 16.1 & 17.6 & 87.7 & 33.5 & 21.1 & 87.7 & 7.6 & 8.5 & 45.6 \\
\hline & Wuqing & DJ & 10.1 & 9.4 & 39.3 & 15.6 & 10.2 & 39.3 & 8.0 & 8.4 & 30.2 \\
\hline & Miyun & $\mathrm{JA}(2006)^{\mathrm{a}}$ & - & - & - & 50.0 & - & - & - & - & - \\
\hline & SDZ & \multicolumn{10}{|c|}{ All-day mean (2004-2006): JA: 32.3 ppbv, SON: 27.5 ppbv, DJ: 19.0 ppbv } \\
\hline
\end{tabular}

${ }^{a}$ Wang et al. (2008), ${ }^{\text {b }}$ Gao et al. (2005), ${ }^{c}$ Meng et al. (2009), ${ }^{d}$ Lin et al. (2008).

or background areas. Nevertheless, their concentrations are mostly on a moderate level during summertime, but due to seasonal variations in solar radiation and temperatures, the reverse is true for $\mathrm{O}_{3} . \mathrm{O}_{3}$ concentrations are the highest in JA and the lowest in DJ. Mean summertime ozone concentrations are $45.2 \pm 32.5 \mathrm{ppbv}$, while mean wintertime $\mathrm{O}_{3}$ falls to $10.1 \pm 9.4 \mathrm{ppbv}$. For the Miyun site, an average daytime $\mathrm{O}_{3}$ of $50 \mathrm{ppbv}$ during JA 2006 was reported (Wang et al., 2008), while the mean $\mathrm{O}_{3}$ level at the SDZ GAW station was found to be $32 \mathrm{ppbv}, 28 \mathrm{ppbv}$, and $19 \mathrm{ppbv}$ for JA, SON, and DJ (2004-2006), respectively (Lin et al., 2008). Compared with the ozone level at Wuqing $(45,16,10 \mathrm{ppbv}$ respectively for JA/SON/DJ), those two sites show lower concentrations during summer, but at $\mathrm{SDZ}, \mathrm{O}_{3}$ is higher during fall and winter. A plausible reason is that during low $\mathrm{O}_{3}$ productivity seasons, ozone in Wuqing is consumed more by primary gas pollutants than in SDZ.

Maximum values of $\mathrm{CO}, \mathrm{SO}_{2}, \mathrm{NO}_{2}$ and $\mathrm{NO}_{\mathrm{x}}$ show that pollution episodes in summer could result in surface concentrations higher than 4 ppmv, $66 \mathrm{ppbv}, 59 \mathrm{ppbv}$, and $96 \mathrm{ppbv}$, respectively, which are all above exceedance standards (see Sect. 2.3). All maximum values of the primary pollutants were observed during the night, mostly due to PBL processes and weak chemical consumption during night time. $\mathrm{O}_{3}$, as a secondary gaseous pollutant, is only produced during daytime under sufficient UV radiation; hence maximum values were normally observed during daytime, reaching up to $194 \mathrm{ppbv}$. Mean daytime $\mathrm{O}_{3}$ concentrations in summer are 64 ppbv, while for night time, $\mathrm{O}_{3}$ is consumed by $\mathrm{NO}_{\mathrm{x}}$, and mean mixing ratio is reduced to ca. $24 \mathrm{ppbv}$, but a maximum night time $\mathrm{O}_{3}$ of $77 \mathrm{ppbv}$ was also observed, which indicates that considerable portion of $\mathrm{O}_{3}$, produced in extremely severe episodes, could not even be consumed during night time. Photochemistry is still very active in early fall, with decreasing temperature and UV radiation flux, photochemistry gradually weakens. During wintertime, surface $\mathrm{O}_{3}$ mixing ratio never exceeded $39.3 \mathrm{ppbv}$, while the mean daytime $\mathrm{O}_{3}$ concentration was around $15.6 \mathrm{ppbv}$.

Overall, Wuqing is in the regionally polluted NCP region, gaseous pollution levels are much higher than those at 
Table 2. Monthly exceedance hour frequency, High Pollution Day (HPD) frequency and Mean Exceeded Amount (MEA) of CO, NO, NO 2 and $\mathrm{O}_{3}$ (calculation method given in Sect. 2.3).

\begin{tabular}{|c|c|c|c|c|c|c|c|c|c|c|}
\hline \multirow[t]{2}{*}{ Month } & \multicolumn{5}{|c|}{ Exceedance Hour/HPD Frequency (\%) } & \multicolumn{5}{|c|}{$\operatorname{MEA}(p p b v)$} \\
\hline & $\mathrm{CO}$ & NO & $\mathrm{NO}_{2}$ & $\mathrm{O}_{3}$ & $\mathrm{SO}_{2}$ & $\mathrm{CO}$ & NO & $\mathrm{NO}_{2}$ & $\mathrm{O}_{3}$ & $\mathrm{SO}_{2}$ \\
\hline Jul & $0.4 / 0$ & $0 / 0$ & $0 / 0$ & $30.7 / 87.0$ & $0 / 0$ & 83.0 & 0 & 0 & 19.7 & 0.0 \\
\hline Aug & $0.6 / 0$ & $0 / 0$ & $0.5 / 0$ & $19.0 / 54.8$ & $0.4 / 0$ & 274.6 & 0 & 5.9 & 20.5 & 18.7 \\
\hline Sep & $0.4 / 0$ & $0.4 / 0$ & $3.2 / 10.0$ & $5.9 / 30$ & $0.3 / 0$ & 858.7 & 7.6 & 5.8 & 6.4 & 1.5 \\
\hline Oct & $7.1 / 12.9$ & $4.4 / 16.1$ & $9.4 / 16.1$ & $1.5 / 3.2$ & $1.8 / 6.5$ & 1381.2 & 24.7 & 7.4 & 5.6 & 13.2 \\
\hline Nov & $13.8 / 23.3$ & $12.0 / 36.7$ & $18.0 / 36.7$ & $0 / 0$ & $15.6 / 40$ & 1295.0 & 34.3 & 10.1 & 0 & 9.3 \\
\hline Dec & $18.8 / 38.7$ & $23.9 / 61.3$ & $17.4 / 35.5$ & $0 / 0$ & $21.4 / 51.6$ & 1132.5 & 41.4 & 10.6 & 0 & 15.7 \\
\hline Jan & $28.5 / 47.6$ & $18.9 / 42.9$ & $19.7 / 38.1$ & $0 / 0$ & $26.2 / 52.4$ & 1716.4 & 25.0 & 7.0 & 0 & 18.3 \\
\hline
\end{tabular}

clean background stations. But from satellite observations, Wuqing is relatively clean compared to city centres. The measurement results are representative of the average pollution level in the NCP region.

To evaluate the severity of different gas pollutions, exceedance hour and HPD frequency of the different gas species have been calculated for each month, along with the MEA (Table 2, method given in Sect. 2.3). In summer, $\mathrm{O}_{3}$ is the major gaseous pollutant, with $87 \%$ of the days and $30.7 \%$ of the total hours exceeding the standards in July. In October, ozone episodes still appeared, but with significantly shorter exceedance frequency and MEA. $\mathrm{NO}_{2}$ and $\mathrm{NO}_{\mathrm{x}}$ pollution episodes gradually gained in frequency and intensity from July to January. During November-January, HPDs of $\mathrm{NO}_{2}$ take up more than a third of the days; with the longest exceedance time in January $(19.7 \%)$ and largest mean exceeded amount in December (10.6 ppbv). NO exceedances generally are more frequent and stronger than $\mathrm{NO}_{2}$ exceedances during November-January, with the highest frequency (61.3\% of all days and $23.9 \%$ of total hours) and largest MEA (41.4 ppbv) in December. Only OctoberJanuary experienced $\mathrm{CO}$ and $\mathrm{SO}_{2}$ HPDs, with HPD occurrence frequencies ranging from 12.9 to $47.6 \%$ and from 6.5 to 52.4 , respectively, with MEAs ranging from 1.4 to 1.7 ppmv and from 9.3 to 18.3 , respectively. Main gaseous pollutants are $\mathrm{O}_{3}$ in summer and $\mathrm{NO}_{2}$ during winter, which is similar to the pollution characteristics of Beijing (Chan and Yao, 2008).

\subsection{Diurnal variations of trace gases and wind speed}

Figure 6 shows the diurnal variations of $\mathrm{CO}, \mathrm{SO}_{2}, \mathrm{NO}$, $\mathrm{NO}_{2}, \mathrm{NO}_{\mathrm{x}}, \mathrm{O}_{3}$ mixing ratio and wind speed during summer (15 July 2009-31 August 2009), fall (1 September 2009-30 November 2009) and winter (1 December 2009-21 January 2010).

CO shows a morning peak at 09:00 a.m. and an evening peak at 09:00 p.m., low during daytime and high during night-time. The traffic in Wuqing is relatively sparse, especially during nighttime, thus $\mathrm{CO}$ emissions from vehicle

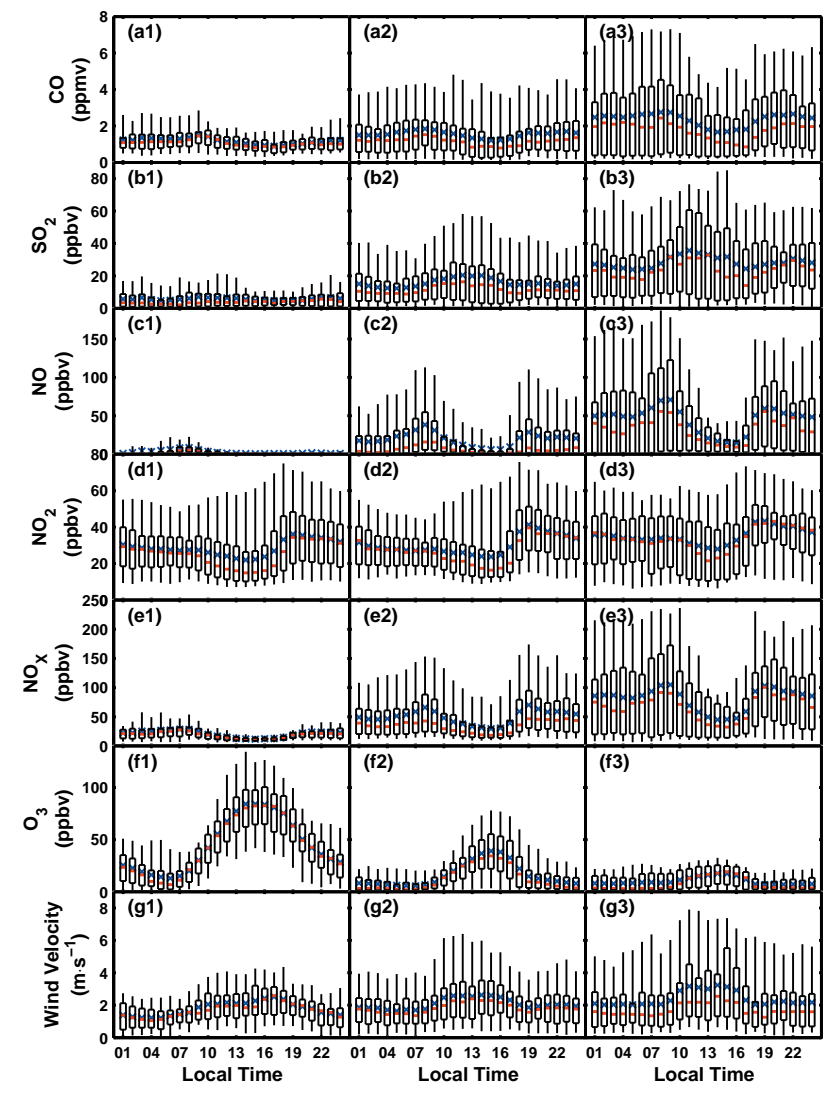

Fig. 6. Diurnal variation of $\mathrm{CO}(\mathbf{a}), \mathrm{SO}_{2}(\mathbf{b}), \mathrm{NO}(\mathbf{c}), \mathrm{NO}_{2}(\mathbf{d}), \mathrm{NO}_{\mathrm{x}}$ (e) and $\mathrm{O}_{3}$ (f) mixing ratio during summer (1), fall (2) and winter (3). The blue cross represents the mean value, while the red bar stands for the median value. The black boxes and whiskers denote the 5, 25, 75 and 95 th percentiles.

exhaust mostly occur during daytime. In fall and winter, domestic heating could result in higher $\mathrm{CO}$ emissions during night-time. Aside from the variation in emissions, this diurnal pattern is high probably caused by the diurnal variation of the PBL height and wind speed. Zhang et al. (2006) used sounding measurements of a suburban site of Beijing 
to determine the PBL height in autumn. Results show that in autumn, the PBL height starts increasing after 07:00 a.m., reaching a maximum around 02:00-03:00 p.m. and starts to decrease afterwards until 09:00 p.m. It can be assumed that in a vast plain region, the boundary layer characteristics are similar. The evening peak of $\mathrm{CO}$ is weaker during summer, because the collapse of the boundary layer might be later in time compared with fall and winter. In summer, wind speed decreases after 06:00 p.m. and reaches its lowest value after midnight, whereas in fall and winter, a low has been reached already at 08:00 and 07:00 p.m. (Fig. $6 \mathrm{~g} 1-\mathrm{g} 3$ ), favouring the accumulation of gases.

$\mathrm{SO}_{2}$ shows a slightly different pattern from that of $\mathrm{CO}$. With the rise of the boundary layer, $\mathrm{SO}_{2}$ gains in concentration reaching a peak at 09:00-11:00 a.m., then decreases until 05:00 p.m. A weak late evening peak can be seen between 09:00-12:00 p.m., which is more significant in winter than in summer. The same phenomenon has been observed at the SDZ GAW station and at Gucheng, a rural site southwest of Beijing (Lin et al., 2008, 2009), with a peak around noon. The increase of $\mathrm{SO}_{2}$ concentration with the development of the boundary layer suggests that the upper air may contain higher concentrations of $\mathrm{SO}_{2}$ than the near surface layer. Stronger turbulence will cause stronger vertical mixing, thus leading to increased mixing ratios. Lin et al. (2008) pointed out that possible sources could be tall chimneys of factories and power plants.

Diurnal variations of $\mathrm{NO}_{\mathrm{x}}$ concentrations are under the strong influence of its emission characteristics, but it seems to be affected by boundary layer processes as well. The diurnal variation pattern of $\mathrm{NO}_{\mathrm{x}}$ resembles to that of $\mathrm{CO}$, with enhanced morning (08:00 a.m.) and evening (07:00 p.m.) peaks, due to the combined effect of daytime traffic emissions and PBL variations. As mentioned before, local traffic is relatively sparse, thus rush hour peaks are unpronounced. Apart from the above mentioned factors, $\mathrm{NO}, \mathrm{NO}_{2}$ diurnal changes are also determined by photochemistry, particularly in summer. In summer $\mathrm{NO}$ is rapidly converted to $\mathrm{NO}_{2}$, showing only a weak morning peak; while in winter, NO dominates because its oxidization is slow and incomplete, thus the evening peak was observed more clearly. $\mathrm{NO}_{2}$, however, shows a stronger evening peak in all seasons. The pattern is almost the same, with slightly higher concentrations in winter.

On average, $\mathrm{O}_{3}$ peaks were observed at 02:00-04:00 p.m. in all seasons. In seasons with weak photochemistry, diurnal patterns are flat, with only weak enhancements during daytime. Late afternoon peaks (around 05:00 p.m.) are often accompanied by south-westerly winds. Median amplitudes of $\mathrm{O}_{3}$ in summer, fall and winter were respectively 83, 34 and 19 ppbv with peaking time being 04:00, 03:00 and 02:00 p.m. In cooler seasons, $\mathrm{O}_{3}$ peaks could be the result of regional mixing or transport, which may also occur during night-time.

\subsection{Influence of meteorology on reactive gases}

\subsubsection{Dependence of gas pollutant concentrations on wind}

Figure 7 shows the wind speed and wind direction dependence map of reactive gas concentrations for summer, fall and winter. The shaded contours indicate the trace gas concentrations for varying wind speeds (radial distance) and wind directions (radial direction). The dashed black line stands for the relative mean gas concentrations of each wind direction, while the solid black line is the relative frequency of all wind directions.

As mentioned before, the prevailing surface wind direction is SW in summer for Wuqing; wind speeds are typically rather low. CO (Fig. 7a1-a3) is a relatively well mixed trace gas. In Wuqing, average concentrations below 1 ppmv could only be detected in the N-W sector and under southerly wind directions, when wind speed exceeded $4 \mathrm{~m} \mathrm{~s}^{-1}$. In the SW and NE directions, $\mathrm{CO}$ concentrations were high under low wind speeds $\left(<2 \mathrm{~m} \mathrm{~s}^{-1}\right)$, but decreased when wind increased to $3-4 \mathrm{~m} \mathrm{~s}^{-1}$. For wind speeds higher than $4 \mathrm{~m} \mathrm{~s}^{-1}$, CO concentrations rose again, which suggests that under persistent slow SW or NE wind, $\mathrm{CO}$ was being transported from regions lying in those directions and increased in Wuqing due to the addition of local to regional sources. With rising wind speed, the local dilution of pollutants became more effective, while the transport might also stem from locations further away. As the wind speed further increased, trace gas concentrations should have been decreasing, thus the increase instead indicated sources of CO situated in those directions. Relating to the average distribution of MOPITT CO, it is highly possible that the NE source is Tangshan and the SW source is the strong regional CO pollution of Hebei. In fall, $\mathrm{NW}$ and $\mathrm{E}$ wind became more frequent, wind speeds were generally higher. $\mathrm{CO}$ mixing ratios were the highest under $\mathrm{NE}$ to SE directions. Relatively high concentrations were also detected in the SW section. However, except for the ENE sector, CO concentrations decreased with increasing wind speed in all directions. The ENE sector provided evidence for the transport of $\mathrm{CO}$ (probably from Tangshan to Wuqing). Dominant wind directions shifted to NW in winter season. Winds with high speed often came from this very direction, accompanied by low concentrations of $\mathrm{CO}$, whereas under slow winds, concentrations were generally high. It suggests that $\mathrm{CO}$ was better mixed in winter than it was in summer, and low wind speeds caused by synoptic conditions could easily lead to local accumulation of $\mathrm{CO}$, while the highest $\mathrm{CO}$ mixing ratios in winter were found in the $\mathrm{NE}$ sector.

From local CO measurements, regional CO characteristics could be detected. $\mathrm{CO}$ concentrations under winds from the SW and NE directions represent the CO pollution characteristics of the NCP region, while with wind from the NW local 

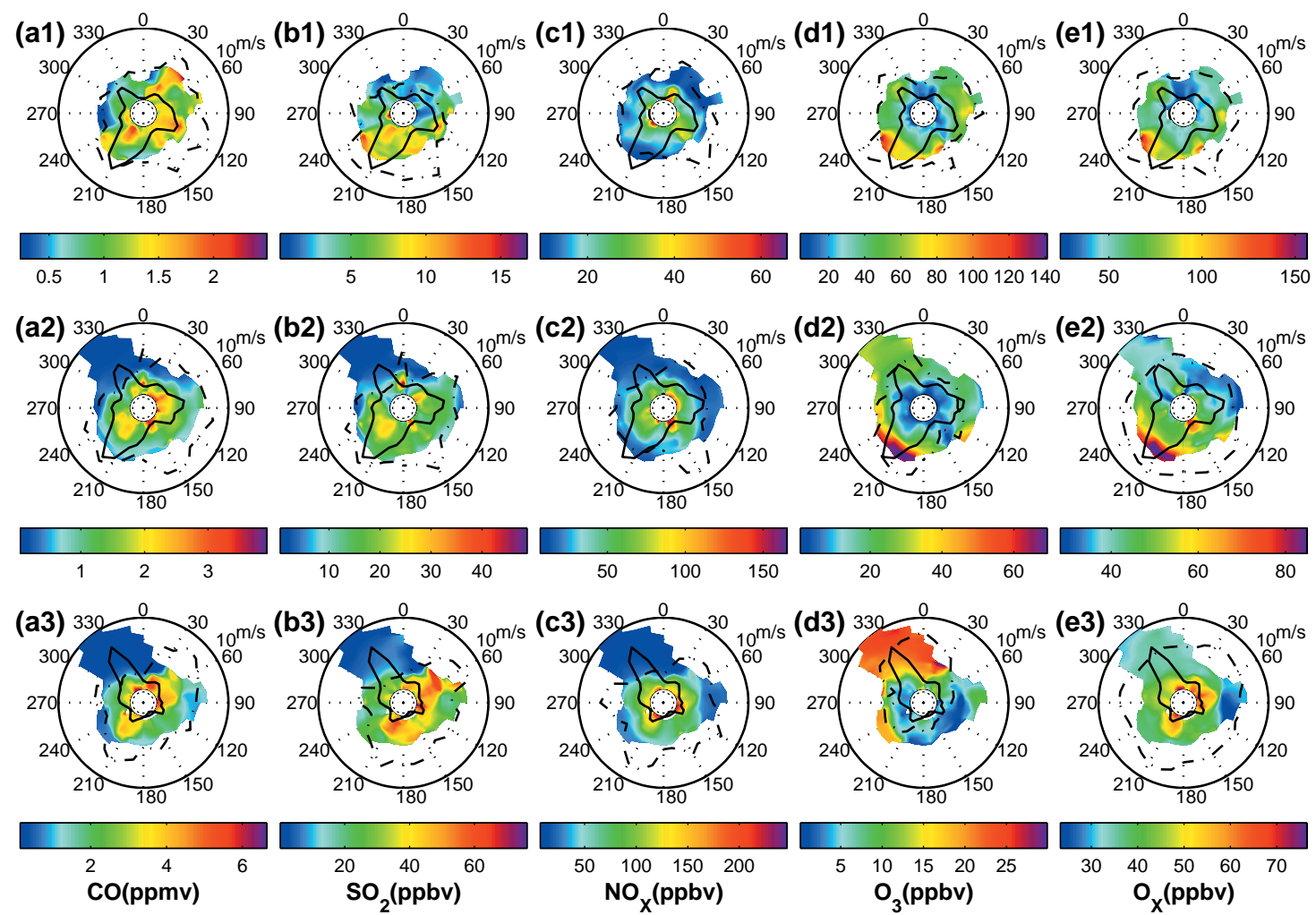

Fig. 7. Wind Dependency map of $\mathrm{CO}(\mathbf{a}), \mathrm{SO}_{2}(\mathbf{b}), \mathrm{NO}_{\mathrm{x}}(\mathbf{c}), \mathrm{O}_{3}(\mathbf{d})$ and $\mathrm{O}_{\mathrm{x}}(\mathbf{e})$ mixing ratio for summer (1), fall (2) and winter (3). Wind speeds are shown from 0 to $10 \mathrm{~m} \mathrm{~s}^{-1}$ (radial distance). The dashed black line shows relative mean gas concentration, while the solid black line is the relative frequency of occurrence versus wind direction both on a scale of 0 to 1 .

$\mathrm{CO}$ mixing ratio was more representative of a regional background concentration.

As discussed in Sect. 3.2, $\mathrm{SO}_{2}$ distributions vary with season, mainly due to domestic heating and slow chemical transformations in winter (Lin et al., 2011). In summer (Fig. 7b1), $\mathrm{SO}_{2}$ mixing ratios were generally low. Relatively higher $\mathrm{SO}_{2}$ concentrations came with local surface winds from SW-SE, which conforms well with the average summertime distribution of OMI SO2 PBL column. While the S-SE sector showed trends of increasing $\mathrm{SO}_{2}$ mixing ratio with wind speed, the SW sector followed the increasedecrease-increase pattern with increasing wind speeds; the decrease was found at $4 \mathrm{~m} \mathrm{~s}^{-1}$. In fall (Fig. $7 \mathrm{~b} 2$ ), $\mathrm{SO}_{2}$ was more evenly distributed among the wind directions; the NW sector showed the lowest and the SW sector the highest concentrations. In winter (Fig. 7b3), $\mathrm{SO}_{2}$ concentrations were the highest under NE wind directions; winds from the south also displayed $\mathrm{SO}_{2}$ mixing ratios between 30 and $50 \mathrm{ppbv}$, while the NW and $\mathrm{W}$ wind mostly brought down fresh non$\mathrm{SO}_{2}$-polluted air. Local $\mathrm{SO}_{2}$ concentrations in Wuqing are representative of the regional $\mathrm{SO}_{2}$ standards and also display the seasonal variation in its source locations.

For trace gases with short lifetimes, such as $\mathrm{NO}_{\mathrm{x}}$, it can be assumed that in-situ measured trace gas mainly stems from local emissions, while the contribution of sources in the surrounding regions is weak. Under such an assumption, concentrations should show a simple decreasing trend with increasing wind speed to a background level. Such a relationship between $\mathrm{NO}_{\mathrm{x}}$ and wind speed was observed as well as modelled in earlier studies (Aldrin and Haff, 2005; Carslaw et al., 2006). In this study, relatively high $\mathrm{NO}_{\mathrm{x}}$ values (Fig. 7c1-c3) in Wuqing were confined to wind speed below $2 \mathrm{~m} \mathrm{~s}^{-1}$. Since $\mathrm{NO}_{\mathrm{x}}$ levels are dominated by local sources and reactions, its concentration is readily diluted and concentrations generally decreased with increasing wind speed, with a mean background value around $10 \mathrm{ppbv}$. In the SE sector, relatively high $\mathrm{NO}_{\mathrm{x}}$ values persisted throughout all wind speeds, showing a decreasing trend after reaching a peak at $1 \mathrm{~m} \mathrm{~s}^{-1}$. This indicates not only the existence of adjacent emission sources, which is most likely the vehicle exhaust in the centre of Wuqing district, but also transport from farther away sources, such as the Tianjin Municipality. $\mathrm{OMI} \mathrm{NO}_{2}$ tropospheric column confirms the fact by showing a large area of elevated $\mathrm{NO}_{2}$ columns $\mathrm{SE}$ to Wuqing. The SW sector also revealed $\mathrm{NO}_{\mathrm{x}}$ at a significantly higher level, especially when accompanied by mild winds. Various factors could have contributed to such a result. Since there are no obvious high concentrations of $\mathrm{NO}_{2}$ visible on the OMI 
$\mathrm{NO}_{2}$ distribution in the $\mathrm{SW}$ direction of Wuqing, the most probable factor would be the synoptic condition associated with mild south-westerly wind, which is favourable for the accumulation of pollutants.

As shown in the wind dependency maps (Fig. 7d1-d3), for all wind directions, $\mathrm{O}_{3}$ concentrations were generally low under slow winds, because high $\mathrm{NO}$ accumulation consumed $\mathrm{O}_{3}$ through chemical reactions. In summer and fall, high $\mathrm{O}_{3}$ was found under W-S wind directions. Summertime measurements conducted by Ran et al. (2011) show high isoprene concentrations, also accompanied by winds from the W-S sector, which may be the reason for the high $\mathrm{O}_{3}$ formation and transport. In winter, $\mathrm{O}_{3}$ production becomes very weak and local $\mathrm{NO}_{\mathrm{x}}$ pollution is severe, which consumes local $\mathrm{O}_{3}$, when fresh NW air is transported to Wuqing under fairly high wind speed, $\mathrm{O}_{3}$ concentrations rose up to background levels in winter.

The "potential ozone" $\mathrm{O}_{\mathrm{x}}\left(\mathrm{O}_{3}+\mathrm{NO}_{2}\right)$ is used as an estimate of the total atmospheric oxidant (Lin et al., 2008). In summer (Fig. 7e1), $\mathrm{O}_{\mathrm{x}}$ was highest in the $\mathrm{SW}$ sector under high wind speeds. For the E-SE-S sector, $\mathrm{O}_{\mathrm{x}}$ increases with rising wind speed, but decreases again after reaching a peak at $3.5 \mathrm{~m} \mathrm{~s}^{-1}$, which suggests that high wind speed can dilute both primary pollutants and secondary formed ones. In fall (Fig. 7e2), $\mathrm{O}_{\mathrm{x}}$ was high when low winds from the SE direction dominated, which was mainly caused by local $\mathrm{NO}_{\mathrm{x}}$ accumulation (see Fig. 7c2). High $\mathrm{O}_{\mathrm{x}}$ were also detected under high winds from the SW direction, which is in favour of $\mathrm{O}_{3}$ production and transport. In winter (Fig. 7e 3), $\mathrm{O}_{\mathrm{x}}$ generally decreased with increasing wind speed. High concentrations were found under low winds from the SW and NE direction, while the lowest concentrations were observed when strong winds came from $\mathrm{E}$.

\subsubsection{Dependence of pollution frequency on wind}

To avoid the large standard deviation in calculating the average gas concentration under given wind directions and wind speeds, the occurrence frequency of gas concentrations reaching above the 75 th percentile $\left(f_{75}\right)$ or below the 25 th percentile $\left(f_{25}\right)$ is utilized to respectively evaluate the occurrence probability of the "relatively polluted" state or the "relatively clean" state (see Sect. 2.5 for detailed description). Figure 8 reveals how $f_{75}$ and $f_{25}$ of different species vary with wind direction and wind speed, respectively for JA, SON and DJ.

For primary gaseous pollutants, $f_{75}$ generally decreases with increasing wind speed, while $f_{25}$ increases with rising wind speed. This is a simple consequence of lower pollution levels being associated with greater mixing and dilution at higher wind speeds. A rise in the frequency of $\mathrm{CO}$ pollution incidents can be clearly seen in the NE and $\mathrm{E}$ directions, $f_{75}(\mathrm{CO})$ shows an increase after $3 \mathrm{~m} \mathrm{~s}^{-1}$ and $5 \mathrm{~m} \mathrm{~s}^{-1}$, respectively, while $f_{25}(\mathrm{CO})$ simultaneously decreases. Summertime $f_{25}\left(\mathrm{SO}_{2}\right)$ is very low and displays no significant variations with either wind direction or wind speed, while $f_{75}\left(\mathrm{SO}_{2}\right)$ is evidently higher under E-SE-S-SW winds and shows either increasing trends with wind speed (E$\mathrm{SE})$ or very weak decreasing trends(S-SW). In fall and winter, $f_{25}\left(\mathrm{SO}_{2}\right)$ gains significantly with increasing wind speed under NW-N winds, while $f_{75}\left(\mathrm{SO}_{2}\right)$ is similar to that of summertime. Results for $\mathrm{NO}_{\mathrm{x}}$ are very consistent with those of $\mathrm{CO}$; only the increasing/decreasing rate of $f_{25} / f_{75}$ is higher. In the S-SW sector, $f_{25}\left(\mathrm{NO}_{\mathrm{x}}\right)$ stays low with increasing wind speed, indicating that this sector is seldom $\mathrm{NO}_{\mathrm{x}}$ clear.

Compared with the primary pollutants, $f_{25}$ and $f_{75}$ of $\mathrm{O}_{3}$ show reversed trends with wind speed. Typically, a decreasing trend of $f_{25}\left(\mathrm{O}_{3}\right)$ can be noted with increasing wind speed, especially during fall and winter, while for $f_{75}\left(\mathrm{O}_{3}\right)$ the opposite is true. However, there are exceptions under certain wind directions. In summer, only $f_{75}\left(\mathrm{O}_{3}\right)$ in the S-SW directions increases with wind speed, while in other directions, occurrence frequency of "relatively polluted" states remain at very low levels. $f_{25}\left(\mathrm{O}_{3}\right)$, however, only increased slowly with easterly wind, in other directions, the occurrence frequency of ozone polluted states decreases with wind speed. The reason that high ozone days appear frequently under S-SW winds has already been stated in the previous section. For N-NW winds, the frequency of $\mathrm{O}_{3}$ concentration falling between the 25 th and 75 th percentiles increases with wind speed, indicating that higher wind speeds are more likely to transport air with background $\mathrm{O}_{3}$ concentrations to Wuqing. In fall and winter, the only exception is seen in the E sector, where $f_{75}\left(\mathrm{O}_{3}\right)$ first increases then decreases with rising wind speed. The decrease in $f_{75}\left(\mathrm{O}_{3}\right)$ might be caused by elevated $\mathrm{NO}_{\mathrm{x}}$ concentrations (or decreased $f_{25}\left(\mathrm{NO}_{\mathrm{x}}\right)$ ) in the $\mathrm{E}$ sector.

Altogether, results are very consistent with those from the wind dependency map (Fig. 7). To summarize and quantify the effect of pollutant emission sources distributed in different wind directions on local trace gas concentrations, a background $f_{75}$ is subtracted from those lying in each wind direction under various wind speeds. Through comparison and analyses, such a background value was determined as the $f_{75}$ values observed under northerly winds. Therefore, the $f_{75}$ values under wind direction $\mathrm{N}$ are subtracted from the $f_{75}$ values corresponding to all other directions (see Eq. (4) in Sect. 2.5), to obtain the frequency increment $\Delta f$. It should be noted that, under very low wind speeds $\left(<2 \mathrm{~m} \mathrm{~s}^{-1}\right)$, the outcome may be influenced by local sources of pollutants.

The wind speed and wind direction distributions of the frequency increment $\Delta f$ are given in Table 3 . As can be seen in the table, sources affecting the frequency of local CO pollution incidents possibly lie in the SW and NE sectors, increasing local $\mathrm{CO}$ pollution occurrence probability in summer by up to $44 \%$ and $37 \%$, respectively. In winter, contributions are not as obvious. The occurrence probability of $\mathrm{SO}_{2}$ pollution is obviously increased by E-SE-S-SW winds. Under the $\mathrm{E}$ wind direction, $\Delta f_{75}\left(\mathrm{SO}_{2}\right)$ first increases with wind speed, then decreases at ca. $5 \mathrm{~m} \mathrm{~s}^{-1}$ (summer and fall) then 


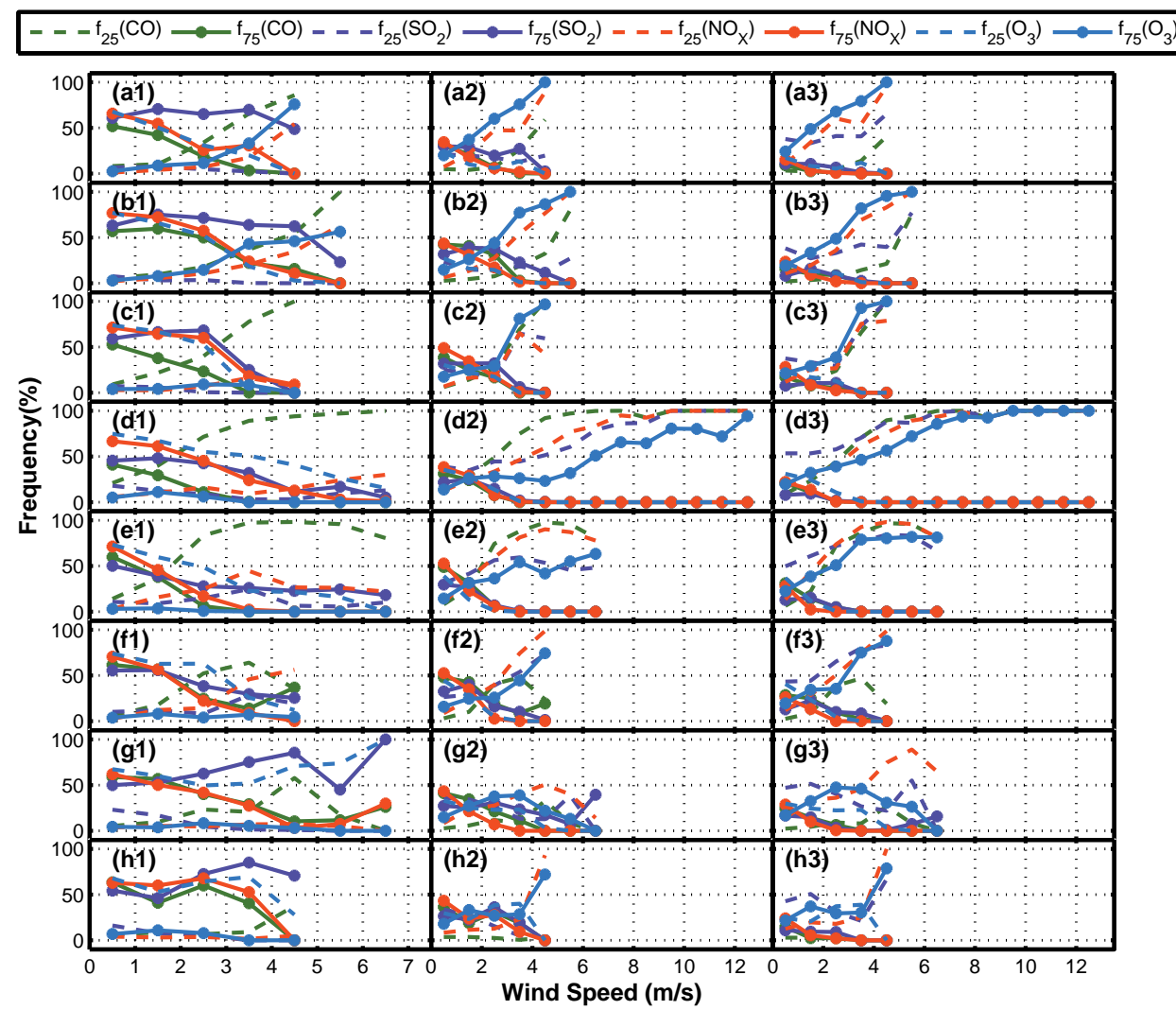

Fig. 8. Variation of frequency $\left(f_{25}\right.$ and $\left.f_{75}\right)$ with wind speed (WS) and wind direction (WD). (a-h) represent S, SW, W, NW, N, NE, E, SE, respectively, while (1-3) stand for summer, fall and winter. Calculation methods are given in Sect. 2.5.

increases again to a maximum value. Especially in summer, high E-SE wind can elevate occurrence frequencies of $\mathrm{SO}_{2}$ pollution by up to $82 \%$. S-SW wind also has remarkable impacts at $2-4 \mathrm{~m} \mathrm{~s}^{-1}$. For $\mathrm{NO}_{\mathrm{x}}$, calm winds from nearly all wind directions can decrease $f_{75}\left(\mathrm{NO}_{\mathrm{x}}\right)$, but for higher wind speeds, the effect of easterly winds is more pronounced, with $\Delta f_{75}\left(\mathrm{NO}_{\mathrm{x}}\right)$ reaching $51 \%$. For summertime $\mathrm{O}_{3}, \mathrm{~S}-\mathrm{SW}$ winds contribute the most ( $\max .76 \%$ ) to increasing the frequency of $\mathrm{O}_{3}$ pollution events, the higher the wind speed, the greater the frequency increment. In fall and winter, $\mathrm{O}_{3}$ concentrations drop to a very low level, due to weakened photochemistry and consumption by high NO concentrations. Thus $f_{75}\left(\mathrm{O}_{3}\right)$ does not represent the frequency of $\mathrm{O}_{3}$ pollution, but rather the frequency of $\mathrm{O}_{3}$ being at background level (unconsumed by $\mathrm{NO}$ ). Hence, in the $\mathrm{N}$ sector, where $f_{75}\left(\mathrm{NO}_{\mathrm{x}}\right)$ is very low, $f_{75}\left(\mathrm{O}_{3}\right)$ display high values. This is the reason that $\Delta f_{75}\left(\mathrm{O}_{3}\right)$ in fall and winter are often negative. With $\mathrm{E}$ winds, $\Delta f_{75}\left(\mathrm{O}_{3}\right)$ have very high negative values, due to severe $\mathrm{O}_{3}$ depletion by NO. It can be noted that, $\Delta f_{75}\left(\mathrm{O}_{3}\right)$ does not show significant variations with different wind directions when wind speeds were low, which is probably due to the nonlinear relationship of ozone to its precursor gases.

\subsubsection{Dependence of ozone on temperature and relative humidity}

Atmospheric temperature is the average kinetic energy of molecules in the air; it directly affects the frequency of collision between molecules, on which chemical reactions rely. It also has direct impact on the mechanism pathway of $\mathrm{O}_{3}$ (e.g., $\mathrm{H}$-abstraction versus $\mathrm{OH}$ addition, Atkinson, 1990) generation and strong correlation with stagnant, sunny (high UV radiation) atmospheric conditions (Jacob et al., 1993). Indirectly, temperature may influence the decomposition rate of PAN and the emission of VOCs, which further complicates the relationship between temperature and $\mathrm{O}_{3}$. Such a relationship has been studied for various locations; generally, the relationship of daily $\mathrm{O}_{3}$ concentration to temperature is nonlinear, $\mathrm{O}_{3}$ concentrations appear to show no dependence on temperature below 294-300 K, but they become strongly dependent on temperature above $305 \mathrm{~K}$ (NRC, 1991). Other studies suggest that $\mathrm{O}_{3}$ increases approximately linearly with temperature, with a slope in the range of $2-$ $8 \mathrm{ppb} \mathrm{K}^{-1}$ (Steiner et al., 2010).

Figure 9 shows observed daily maximum $\mathrm{O}_{3}$ values in relation with daily maximum temperatures. The figure also marks the exceedance standard for $\mathrm{O}_{3}$ (horizontal red dashed 
Table 3. Wind Speed (WS) and Wind Direction (WD) distribution of frequency increment $\Delta f$. Calculation methods are given in Sect. 2.5 .

\begin{tabular}{|c|c|c|c|c|c|c|c|c|c|c|c|c|c|c|c|c|c|c|c|c|c|c|}
\hline \multirow{3}{*}{$\begin{array}{l}\text { Trace } \\
\text { Gas }\end{array}$} & \multirow{3}{*}{$\begin{array}{r}\text { Wind } \\
\left(\mathrm{m} \mathrm{s}^{-1}\right)\end{array}$} & \multicolumn{21}{|c|}{$\Delta f_{75}(\%)$} \\
\hline & & \multicolumn{7}{|c|}{ Summer (15 Jul-31 Aug 2009) } & \multicolumn{7}{|c|}{ Fall (1 Sep-30 Nov 2009) } & \multicolumn{7}{|c|}{ Winter (1 Dec 2009-21 Jan 2010) } \\
\hline & & $\mathrm{S}$ & SW & $\mathrm{W}$ & NW & $\mathrm{NE}$ & $\mathrm{E}$ & $\mathrm{SE}$ & $\mathrm{S}$ & SW & $\mathrm{W}$ & NW & $\mathrm{NE}$ & $\mathrm{E}$ & SE & $\mathrm{s}$ & SW & $\mathrm{W}$ & NW & $\mathrm{NE}$ & $\mathrm{E}$ & SE \\
\hline \multirow{7}{*}{$\mathrm{CO}$} & $0-1$ & -8.1 & -3.0 & -7.1 & -18.8 & 1.8 & -1.0 & 3.6 & -17.7 & -6.6 & -10.3 & -17.7 & -0.9 & -7.7 & -12.5 & -22.0 & -15.5 & -14.2 & -10.3 & -2.6 & -6.6 & -16.4 \\
\hline & $1-2$ & 4.4 & 21.6 & -0.1 & -8.5 & 18.6 & 18.7 & 3.1 & -10.7 & 9.3 & -6.5 & -7.2 & 11.2 & 2.9 & -12.5 & -11.6 & -4.1 & -6.4 & -3.4 & 10.7 & 0.0 & -11.9 \\
\hline & $2-3$ & 12.5 & 44.0 & 17.3 & 5.0 & 18.6 & 34.2 & 54.0 & 0.7 & 25.3 & 10.9 & 1.7 & 12.9 & 15.3 & 25.0 & -3.4 & 4.0 & 0.4 & -3.7 & 4.8 & 1.6 & -2.4 \\
\hline & $3-4$ & 3.4 & 22.1 & 0.0 & 0.4 & 13.8 & 29.1 & 40.6 & 0.3 & 2.6 & 0.0 & 0.0 & 8.7 & 11.2 & 18.8 & 0.0 & 1.1 & 0.0 & 0.0 & 2.1 & 0.4 & 0.0 \\
\hline & $4-5$ & 0.0 & 15.5 & 0.0 & 0.0 & 36.6 & 10.3 & 0.0 & 0.0 & 0.0 & 0.0 & 0.0 & 19.3 & 0.0 & 0.0 & 0.0 & 0.0 & 0.0 & 0.0 & 0.0 & 0.0 & 0.0 \\
\hline & $5-6$ & - & 0.0 & - & 0.0 & - & 11.6 & - & - & 0.0 & - & 0.0 & - & 0.0 & - & - & 0.0 & - & 0.0 & - & 0.0 & - \\
\hline & $6-7$ & - & - & - & 0.0 & - & 26.1 & - & - & - & - & 0.0 & - & 0.0 & - & - & - & - & 0.0 & - & 0.0 & - \\
\hline \multirow{7}{*}{$\mathrm{SO}_{2}$} & $0-1$ & 10.7 & 12.9 & 9.1 & -4.7 & 5.3 & -0.2 & 4.3 & 0.3 & 2.1 & 2.2 & -7.9 & 2.9 & -2.5 & -3.1 & -2.2 & -4.8 & -5.2 & -4.9 & 0.1 & 3.8 & -2.0 \\
\hline & $1-2$ & 31.4 & 35.7 & 27.2 & 9.0 & 16.6 & 13.5 & 6.9 & 2.3 & 12.2 & 5.4 & -1.3 & 13.3 & -1.2 & -4.2 & -4.6 & 0.6 & -5.0 & -5.9 & 7.5 & -0.5 & -5.7 \\
\hline & $2-3$ & 37.2 & 43.5 & 40.4 & 14.7 & 10.4 & 34.5 & 44.7 & 12.8 & 31.1 & 25.3 & 7.8 & 9.0 & 23.9 & 29.3 & 1.6 & 3.3 & 5.7 & -3.3 & 5.1 & -1.7 & 4.0 \\
\hline & $3-4$ & 43.9 & 37.8 & -1.0 & 6.0 & 3.7 & 49.3 & 59.3 & 26.2 & 21.8 & 5.1 & 0.8 & 9.4 & 22.4 & 18.3 & 1.1 & 2.5 & 0.0 & 0.0 & 8.5 & 0.0 & 0.0 \\
\hline & $4-5$ & 26.0 & 39.5 & -22.8 & -11.2 & 2.7 & 62.7 & 48.0 & 2.2 & 11.3 & 0.0 & 0.2 & 1.2 & 17.4 & 0.0 & 0.0 & 0.0 & 0.0 & 0.0 & 0.0 & 0.8 & 0.0 \\
\hline & $5-6$ & - & -1.3 & - & -7.4 & - & 20.7 & - & - & 0.0 & - & 0.0 & - & 7.4 & - & - & 0.0 & - & 0.0 & - & 7.4 & - \\
\hline & $6-7$ & - & - & - & -13.1 & - & 81.9 & - & - & - & - & 0.0 & - & 39.4 & - & - & - & - & 0.0 & - & 15.8 & - \\
\hline \multirow{7}{*}{$\mathrm{NO}_{\mathrm{x}}$} & $0-1$ & -5.6 & 5.4 & 0.1 & -4.6 & -0.8 & -9.3 & -8.3 & $\mid-18.4$ & -9.3 & -3.9 & -14.3 & -0.1 & -9.7 & -9.5 & -12.9 & -4.7 & 0.0 & -6.1 & -2.0 & 0.5 & -4.1 \\
\hline & $1-2$ & 8.9 & 26.4 & 18.7 & 15.6 & 10.9 & 4.4 & 14.4 & -4.9 & 8.2 & 11.8 & 6.5 & 12.4 & -1.0 & 1.3 & 0.8 & 6.8 & 6.2 & 11.3 & 11.0 & 7.6 & 3.2 \\
\hline & $2-3$ & 9.0 & 40.5 & 43.1 & 28.3 & 5.4 & 24.8 & 50.9 & -0.1 & 11.3 & 11.9 & 1.9 & -3.1 & 1.2 & 21.9 & 0.6 & 1.9 & 2.5 & 0.6 & 0.0 & 0.5 & 2.2 \\
\hline & $3-4$ & 28.5 & 21.6 & 16.0 & 21.8 & 6.7 & 25.2 & 50.6 & 1.7 & 1.6 & 0.8 & 0.4 & 0.0 & 0.0 & 9.3 & 0.0 & 0.0 & 0.0 & 0.0 & 0.0 & 0.0 & 0.0 \\
\hline & $4-5$ & 0.0 & 10.7 & 8.8 & 12.7 & 0.0 & 3.3 & 0.0 & 0.0 & 0.0 & 0.0 & 0.0 & 0.0 & 0.0 & 0.0 & 0.0 & 0.0 & 0.0 & 0.0 & 0.0 & 0.0 & 0.0 \\
\hline & $5-6$ & - & 0.0 & - & 2.9 & - & 7.4 & - & - & 0.0 & - & 0.0 & - & 0.0 & - & - & 0.0 & - & 0.0 & - & 0.0 & - \\
\hline & $6-7$ & - & - & - & 1.0 & - & 29.7 & - & - & - & - & 0.0 & - & 0.0 & - & - & - & - & 0.0 & - & 0.0 & - \\
\hline \multirow{7}{*}{$\mathrm{O}_{3}$} & $0-1$ & -0.6 & -0.1 & 1.0 & 2.1 & 0.8 & 1.3 & 3.8 & 5.6 & 0.3 & 3.0 & -0.7 & 1.3 & 0.5 & 3.6 & 1.7 & -3.2 & -1.3 & -2.8 & -3.1 & -5.5 & -0.9 \\
\hline & $1-2$ & 5.0 & 4.1 & 0.6 & 7.5 & 4.4 & 0.2 & 7.3 & 5.6 & -5.3 & -6.6 & -5.3 & -7.0 & -4.3 & 1.5 & 10.1 & -5.3 & -9.5 & -6.4 & -4.2 & -6.2 & -1.6 \\
\hline & $2-3$ & 10.8 & 13.8 & 8.3 & 5.5 & 3.3 & 7.7 & 7.1 & 23.7 & 7.6 & -7.2 & -8.1 & -10.5 & 1.3 & -9.5 & 16.8 & -2.4 & -12.3 & -11.9 & -15.5 & -3.5 & -21.5 \\
\hline & 3-4 & 32.9 & 42.7 & 8.3 & -0.2 & 6.8 & 5.2 & -0.2 & 21.7 & 23.1 & 27.0 & -28.0 & -9.6 & -15.3 & -25.6 & 0.3 & 2.9 & 13.7 & -32.6 & -3.8 & -33.1 & -48.8 \\
\hline & $4-5$ & 75.9 & 45.8 & 0.0 & 0.0 & 4.5 & 3.0 & 0.0 & 58.1 & 44.6 & 55.0 & -18.7 & 32.5 & -20.0 & 30.2 & 19.5 & 14.9 & 19.5 & -24.0 & 7.3 & -49.7 & -1.7 \\
\hline & $5-6$ & - & 56.3 & - & 0.0 & - & 0.0 & - & - & 44.9 & - & -23.2 & - & -42.1 & - & - & 18.0 & - & -9.8 & - & -55.8 & - \\
\hline & $6-7$ & - & - & - & 0.0 & - & 0.0 & - & - & - & - & -12.4 & - & -63.3 & - & - & - & - & 4.3 & - & -81.4 & - \\
\hline
\end{tabular}

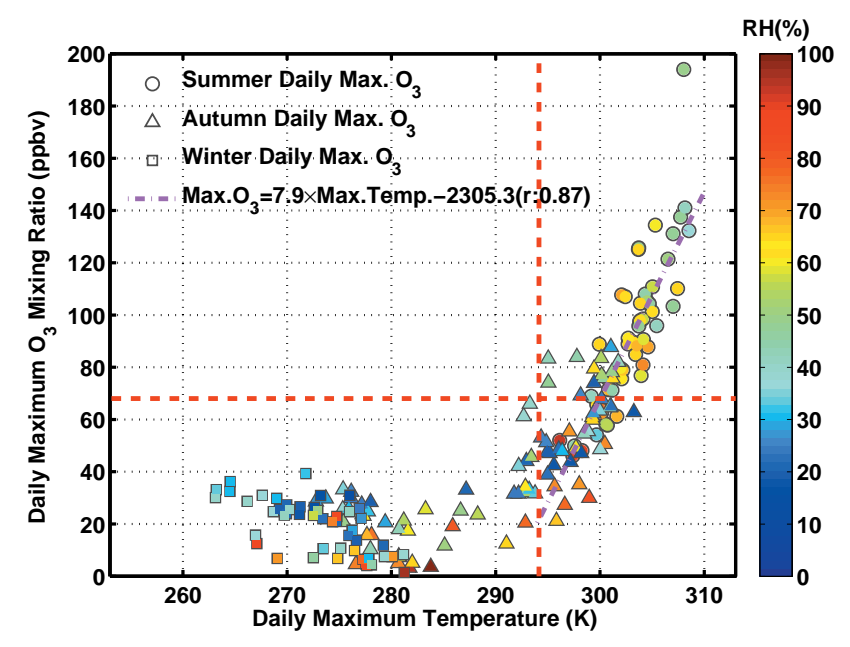

Fig. 9. Dependence of daily maximum ozone concentrations on daily maximum temperature and current $\mathrm{RH}(\mathrm{RH}$ at the occurrence time of the ozone peak). Round dots stand for summer time data, triangles for fall data and squares for winter data; colours show current relative humidity. The horizontal red dashed line stands for the $\mathrm{O}_{3}$ exceedance standard defined in Sect. 2.3; the vertical red dashed line, stands for the temperature cut-off, under which there has been no ozone exceedance detected; the magenta dashed line shows a regression between daily maximum temperature and daily maximum ozone above the temperature cut off. line) and the temperature value (vertical red dashed line), below which $\mathrm{O}_{3}$ never exceeded given standards. It can be noted that, for atmospheric temperatures greater than $294 \mathrm{~K}, \mathrm{O}_{3}$ concentrations increased almost linearly with temperature, with a slope of $7 \mathrm{ppb} \mathrm{K}^{-1}$, but when atmospheric temperatures sank under $294 \mathrm{~K}$, ozone concentrations kept below the exceedance level. For temperatures lower than 289 $291 \mathrm{~K}, \mathrm{O}_{3}$ concentrations were not dependent on temperature, but on other meteorological parameters. It should be noted that the observed correlation between daily maximum $\mathrm{O}_{3}$ and temperature cannot be attributed solely to temperature dependence of chemical reaction rates because daily maximum temperature is highly dependent on the intensity of solar radiation, which the major driver of photochemical $\mathrm{O}_{3}$ production.

In summer, high RH and low RH both were accompanied by relatively lower daily maximum $\mathrm{O}_{3}$ mixing ratios, while RH between $40 \%$ and $60 \%$ often appeared with high $\mathrm{O}_{3}$ mixing ratios. A reasonable explanation would be that high RH is often associated with cloudy and rainy days in summer, thus weak UV radiation might reduce ozone productivity; while low RH in summer are mostly associated with northerly wind from the inland, bringing down fresh less polluted air with low ozone precursor concentrations. It is also evident that, in winter, maximum $\mathrm{O}_{3}$ concentrations were higher under low relative humidity, which may have two reasons. Firstly, low relative humidity often occurs when the NCP region was controlled by a high pressure ridge, mostly resulting in clear days with strong radiation, 
thus promoting some photochemical reactions. Secondly, the above mentioned weather system was mostly accompanied by NW winds, which brought down fresh air with low precursor gas concentrations, thus the produced $\mathrm{O}_{3}$ was not depleted by high local NO concentrations. Also, high pressure systems with downdrafts may bring down ozone rich air from the upper level.

\section{Conclusions}

Measurements of surface trace gases at Wuqing from the period 9 July 2009-21 January 2010 and ancillary data were used to study the characteristics of pollution in the North China Plain and the impact of meteorology on local trace gas concentrations.

Annual mean distributions of trace gases and AOD reveal the currently highly polluted state of the NCP. Wuqing in comparison to the neighbouring mega-cities (Beijing and Tianjin) is relatively clean. The lack of significant local emission sources and the location of Wuqing determine that the site is highly representative of the regional pollution state.

Mixing ratios of gaseous pollutants were on a significantly higher level than rural stations to the north of Beijing city centre (Miyun, Wang et al., 2008; SDZ, Gao et al., 2005; Meng et al., 2009; Lin et al., 2008]. Mean daytime $\mathrm{O}_{3}$ varied between 64.1 (JA) and 15.6 (DJ) ppbv. $\mathrm{CO}, \mathrm{SO}_{2}$, $\mathrm{NO}_{2}, \mathrm{NO}_{\mathrm{x}}$, however, showed reversed seasonality, with the lowest values in JA, respectively being $1.2 \mathrm{ppmv}, 5.7 \mathrm{ppbv}$, $17.9 \mathrm{ppbv}$ and $20.4 \mathrm{ppbv}$, and the highest values in DJ, reaching $2.4 \mathrm{ppmv}, 28.5 \mathrm{ppbv}, 35.1 \mathrm{ppbv}$ and $80.8 \mathrm{ppbv}$, respectively. Major gaseous pollutants at Wuqing are $\mathrm{O}_{3}$ in summer and $\mathrm{NO}_{\mathrm{x}}$ in winter.

Mean diurnal patterns of primary gaseous pollutants are high probably determined by boundary layer processes (variations of mixing height, vertical turbulence and horizontal wind velocity) and emission characteristics, showing morning and evening peaks. For $\mathrm{NO}_{\mathrm{x}}$, it is primarily the result of rush hour emissions in combination with photochemistry; while for $\mathrm{CO}$, it is more a boundary layer effect. $\mathrm{SO}_{2}$ showed an early noon peak and an insignificant evening peak, probably caused by emission sources outside the nocturnal boundary layer. Further research on the vertical profile of $\mathrm{SO}_{2}$ or its vertical flux is required. Secondary gas pollutant, $\mathrm{O}_{3}$, peaked between 02:00 to 04:00 p.m. on average.

Wind speed and wind direction showed deterministic impacts on trace gas pollution levels, providing information on regional pollution characteristics. Generally, high concentrations of relatively long-lived gaseous pollutants came with wind directions from SW-SE and NE with very high frequencies. Short-lived gases, such as $\mathrm{NO}_{\mathrm{x}}$, mainly displayed high concentrations under calm winds, but also suggested transport form the $\mathrm{SE} . \mathrm{O}_{3}$ showed low concentrations under calm winds, which were accompanied by high $\mathrm{NO}_{\mathrm{x}}$. High concentrations of $\mathrm{O}_{3}$ were found under high wind speed, in wind conditions with low levels of $\mathrm{NO}_{\mathrm{x}}$. The S-SW directions especially showed high concentrations of $\mathrm{O}_{3}$ and high occurrence frequency of $\mathrm{O}_{3}$ pollution during summer, probably due to the high isoprene concentrations associated with those wind directions. No transport of plumes from Beijing to Wuqing was detected, since air associated with NW winds were mostly clean, especially under large wind speeds.

Temperature is another meteorological factor that influences $\mathrm{O}_{3}$ concentrations. For atmospheric temperatures higher than $294 \mathrm{~K}$, the $\mathrm{O}_{3}$ concentration increased linearly with temperature and frequently exceeded the defined standard, particularly at temperatures over $300 \mathrm{~K}$; for air temperatures lower than $294 \mathrm{~K}$, the $\mathrm{O}_{3}$ concentration showed no correlation with temperature and no $\mathrm{O}_{3}$ exceedance was observed. For temperatures beneath $289 \sim 291 \mathrm{~K}, \mathrm{O}_{3}$ concentrations depended on other meteorological parameters instead of the temperature. This temperature limit is $9 \mathrm{~K}$ lower than that proposed by the NRC (1991).

Overall, this study provides important information on the pollution state and the characteristics of various gas pollutants. $\mathrm{CO}$ and $\mathrm{SO}_{2}$ are closely related to aerosol pollution, $\mathrm{O}_{3}$ influences the aging of atmospheric aerosols and $\mathrm{SO}_{2}$ levels may have great impacts on aerosol hygroscopicity, optical properties and $\mathrm{CCN}$ activations.

Acknowledgements. We gratefully thank the staff of the Wuqing Meteorological Station for their logistic support. Funds for this research were provided by the National Natural Science Foundation of China Project 40875001 and 40775074, the 973 Program (2011CB403402), and the Basic Research Fund of Chinese Academy of Meteorological Sciences (2008Z011).

Edited by: D. Covert

\section{References}

Aldrin, M. and Haff, I. H.: Generalised additive modelling of air pollution, traffic volume and meteorology, Atmos. Environ., 39, 2145-2155, 2005.

Atkinson R.: Gas-phase tropospheric chemistry of organic compounds: A review, Atmos. Environ., 24A, 1-41, 1990.

Carslaw, D. C., Beevers, S. D., Ropkins, K., and Bell, M. C.: Detecting and quantifying aircraft and other on-airport contributions to ambient nitrogen oxides in the vicinity of a large international airport, Atmos. Environ., 40, 5424-5434, 2006.

Chan, C. K. and Yao, X.: Air pollution in mega cities in China, Atmos. Environ., 42(1), 1-42, 2008.

Chen, Y., Zhao, C., Zhang, Q., Deng, Z., and Huang, M.: Aircraft study of Mountain Chimney Effect of Beijing, China, J. Geophys. Res., 114, D08306, doi:10.1029/2008JD010610, 2009.

Chen, Z. H., Cheng, S. Y., Li, J. B., Guo, X. R., Wang, W. H., and Chen, D. S.: Relationship between atmospheric pollution processes and synoptic pressure patterns in northern China, Atmos. Environ., 42(24), 6078-6087, 2008.

Dickerson, R. R., Kondragunta, S., Stenchikov, G., Civerolo, K. L., Doddridge, B. G., and Holben, B. N.: The Impact of Aerosols on 
Solar Ultraviolet Radiation and Photochemical Smog, Science, 278(5339), 827-830, doi:10.1126/science.278.5339.827, 1997.

Ding, A. J., Wang, T., Thouret, V., Cammas, J.-P., and Ndlec, P.: Tropospheric ozone climatology over Beijing: analysis of aircraft data from the MOZAIC program, Atmos. Chem. Phys., 8, 1-13, doi:10.5194/acp-8-1-2008, 2008.

Fischer, H., Kormann, R., Klüpfel, T., Gurk, Ch., Königstedt, R., Parchatka, U., Mühle, J., Rhee, T. S., Brenninkmeijer, C. A. M., Bonasoni, P., and Stohl, A.: Ozone production and trace gas correlations during the June 2000 MINATROC intensive measurement campaign at Mt. Cimone, Atmos. Chem. Phys., 3, 725-738, doi:10.5194/acp-3-725-2003, 2003.

Gao, J., Wang, T., Ding, A. J., and Liu, C. B.: Observational study of ozone and carbon monoxide at the summit of mount Tai (1534 m a.s.1.) in central-eastern China, Atmos. Environ., 39(26), 4779-4791, 2005.

Greene, J. S., Kalkstein, L. S., Ye, H., and Smoyer, K.: Relationships between synoptic climatology and atmospheric pollution at 4 US cities, Theor. Appl. Climatol., 62, 163-174, 1999.

Hao, J. M. and Wang, L. T.: Improving urban air quality in China: Beijing case study, J. AirWaste Manage. Assoc., 55, 1298-1305, 2005.

Jacob, D. J., Logan, J. A., Yevich, R. M., Gardner, G. M., Spivakovsky, C. M., Wofsy, S. C., Munger, J. W., Sillman, S., Prather, M. J., Rodgers, M. O., Westberg, H., and Zimmerman, P. R.: Simulation of Summertime Ozone over North America, J. Geophys. Res., 98, 14797-14816, 1993.

Jaffe, D. A., Mahura, A., Kelley, J., Atkins, J., Novelli, P. C., and Merrill, J.: Impact of Asian emissions on the remote North Pacific atmosphere: interpretation of CO data from Shemya, Guam, Midway, and Mauna Loa, J. Geophys. Res., 101, 2037-2048, 1997.

Jenkin, M. E. and Clemitshaw, K. C.: Ozone and other secondary photochemical pollutants chemical processes governing the formation in the planetary boundary layer, Atmos. Environ., 34, 2499-2577, 2000.

Jones, A. M., Harrison, R. M., and Baker, J.: The wind speed dependence of the concentrations of airborne particulate matter and $\mathrm{NO}_{\mathrm{x}}$, Atmos. Environ., 44(13), 1682-1690, 2010.

Kan, H. and Chen, B.: Particulate air pollution in urban areas of Shanghai, China: health-based economic assessment, Sci. Total Environ., 322, 71-79, 2004.

Kato, N. and Akimoto, H.: Anthropogenic emissions of SO2 and $\mathrm{NO}_{\mathrm{x}}$ in Asia: Emission inventories, Atmos. Environ., 26(19), 2997-3017, 1994.

Korsog, P. E. and Wolff, G. T.: An examination of tropospheric ozone trends in the northeastern U.S. (1973-1983) using a robust statistical method, Atmos. Environ., 25B, 47-57, 1991.

Li, C. C., Mao, J .T., Lau, K. H. A., Chen, J. C., Yuan, Z. B., Liu, X. Y., Zhu, A. H., and Liu, G. Q.: Characteristics of distribution and seasonal variation of aerosol optical depth in eastern China with MODIS products, Chinese Sci. Bull., 48(22), 2488-2495, 2003.

Lin, W., Xu, X., Zhang, X., and Tang, J.: Contributions of pollutants from North China Plain to surface ozone at the Shangdianzi GAW Station, Atmos. Chem. Phys., 8, 5889-5898, doi:10.5194/acp-8-5889-2008, 2008.

Lin, W., Xu, X., Ge, B., and Zhang, X.: Characteristics of gaseous pollutants at Gucheng, a rural site southwest of Beijing, J. Geophys. Res., 114, D00G14, doi:10.1029/2008JD010339, 2009.
Lin, W., Xu, X., Ge, B., and Liu, X.: Gaseous pollutants in Beijing urban area during the heating period 2007-2008: variability, sources, meteorological and chemical impacts, Atmos. Chem. Phys. Discuss., 11, 6919-6956, doi:10.5194/acpd-116919-2011, 2011.

Liu, C. M., Huang, C. Y., Shieh, S. L., and Wu, C. C.: Important meteorological parameters for ozone episodes experienced in the Taipei Basin, Atmos. Environ., 28(24), 159-173, 1994.

Liu, P., Zhao, C., Zhang, Q., Deng, Z., Huang, M., Ma, X., and Tie, X.: Aircraft study of aerosol vertical distributions over Beijing and their optical properties, Tellus B, 61, 756-767, 2009.

Meagher, J. F., Stockburger, L., Bailey, E. M., and Huff, O.: The oxidation of sulfur dioxide to sulfate aerosols in the plume of a coal-fired power plant, Atmos. Environ., 12(11), 2197-2203, 1978.

Meng, Z. Y., Xu, X. B., Yan, P., Ding, G. A., Tang, J., Lin, W. L., Xu, X. D., and Wang, S. F.: Characteristics of trace gaseous pollutants at a regional background station in Northern China, Atmos. Chem. Phys., 9, 927-936, doi:10.5194/acp-9-927-2009, 2009.

NRC (National Research Council): Rethinking the ozone problem in urban and regional air pollution, National Academy Press, Washington, DC, 1991.

OMSO2Readme file: available at: http://so2.umbc.edu/omi/omi docs.html, last accessed: 3 November 2010.

Parrish, D. D., Holloway, J. S., Trainer, M., Murphy, P. C., Forbes, G. L. and Fehsenfeld, F. C.: Export of North-American ozone pollution to the North-Atlantic ocean, Science, 259 (5100), 1436-1439, 1993.

Parrish, D. D., Trainer, M., Holloway, J. S., Yee, J. E., Warshawsky, M. S. and Fehsenfeld, F. C.: Relationships between ozone and carbon monoxide at surface sites in the North Atlantic region, J. Geophys. Res., 103, 13357-13376, 1998.

PORG: Ozone in the United Kingdom. Fourth Report of the UK Photochemical Oxidants Review Group, Department of the Environment, Transport and the Regions, London, 1997

Prosmitis, A. B., Diapouli, E., and Chaloulakou, S. N.: Organic and elemental carbon particulate continuous field measurements in the Athens urban area, 8th International Conference on Environmental Science and Technology, Lernos Island, Greece, 2003.

Ran, L., Zhao, C., Geng, F., Tie, X., Tang, X., Peng, L., Zhou, G., Yu, Q., Xu, J., and Guenther, A.: Ozone photochemical production in urban Shanghai, China: Analysis based on ground level observations, J. Geophys. Res., 114, D15301, doi:10.1029/2008JD010752, 2009.

Ran, L., Zhao, C. S., Xu, W. Y., Lu, X. Q., Han, M., Lin, W. L., Yan, P., Xu, X. B., Deng, Z. Z., Ma, N., Liu, P. F., Yu, J., Liang, W. D., and Chen, L. L.: VOC reactivity and its effect on ozone production during the HaChi summer campaign, Atmos. Chem. Phys. Discuss., 11, 8595-8623, doi:10.5194/acpd11-8595-2011, 2011.

Saxena, P. and Seigneur, C.: On the oxidation of $\mathrm{SO}_{2}$ to sulfate in atmospheric aerosols, Atmos. Environ., 21(4), 807-812, 1987.

Shao, M., Tang, X., Zhang, Y., and Li, W.: City clusters in China: air and surface water pollution, Front. Ecol. Environ., 4(7), 353361, 2006.

Steiner, A. L., Davis, A. J., Sillman, S., Owen, R. C., Michalak, A. M. and Fiore, A. M.: Observed suppression of ozone formation at extremely high temperatures due to chemical and bio- 
physical feedbacks, P. Natl. Acad. Sci., 107(46), 19685-19690, doi:10.1073/pnas.1008336107, 2010.

Streets, D. G. and Waldhoff, S. T.: Present and future emissions of air pollutants in China: $\mathrm{SO} 2, \mathrm{NO}_{\mathrm{x}}$, and $\mathrm{CO}$, Atmos. Environ., 34(3), 363-374, 2000.

Tang, G., Li, X., Wang, Y., Xin, J., and Ren, X.: Surface ozone trend details and interpretations in Beijing, 2001-2006, Atmos. Chem. Phys., 9, 8813-8823, doi:10.5194/acp-9-8813-2009, 2009.

Ulas, I., Mete, T., and Orhan, Y.: Analysis of major photochemical pollutants with meteorological factors for high ozone days in Istanbul, Turkey, Water Air Soil Pollut., 175, 335-359, 2006.

van Donkelaar, A., Martin, R. V., Brauer, M., Kahn, R., Levy, R., Verduzco, C., and Villeneuve, P. J.: Global estimates of ambient fine particulate matter concentrations from satellite-based aerosol optical depth: Development and application, Environ Health Perspect, 118, 847-855, doi:10.1289/ehp.0901623, 2010.

Wang, T., Carroll, M. A., Alber, G. M., Owens, K. R., Duderstadt, K. A., Markevitch, A., Parrish, D. D., Holloway, J., Fehsenfeld, F. C., Forbes, G. and Ogren, J.: Groundbased measurements of $\mathrm{NO}_{\mathrm{x}}$ and total reactive oxidized Nitrogen $\left(\mathrm{NO}_{\mathrm{y}}\right)$ at Sable Island, Nova Scotia during the NARE 1993 Summer Intensive. J. Geophys. Res., 101, 28947-28960, 1996.

Wang, T., Lam, K. S., Chan, L. Y., Carroll, M. A., and Lee, A. S. Y.: Trace gas measurements in coastal Hong Kong during the PEMWESWEST (B), J. Geophys. Res., 102, 28575-28588, 1997.

Wang, T., Ding, A., Gao, J., Wu, W. S., and America, N.: Strong ozone production in urban plumes from Beijing, China, Geophys. Res. Lett., 33, 1-5, 2006.
Wang, Y., McElroy, M. B., Munger, J. W., Hao, J., Ma, H., Nielsen, C. P., and Chen, Y.: Variations of $\mathrm{O}_{3}$ and $\mathrm{CO}$ in summertime at a rural site near Beijing, Atmos. Chem. Phys., 8, 6355-6363, doi:10.5194/acp-8-6355-2008, 2008.

Wang, Y., Hao, J., McElroy, M. B., Munger, J. W., Ma, H., Chen, D., and Nielsen, C. P.: Ozone air quality during the 2008 Beijing Olympics: effectiveness of emission restrictions, Atmos. Chem. Phys., 9, 5237-5251, doi:10.5194/acp-9-5237-2009, 2009.

Wang, Y., Munger, J. W., Xu, S., McElroy, M. B., Hao, J., Nielsen, C. P., and Ma, H.: $\mathrm{CO}_{2}$ and its correlation with $\mathrm{CO}$ at a rural site near Beijing: implications for combustion efficiency in China, Atmos. Chem. Phys., 10, 8881-8897, doi:10.5194/acp-10-88812010, 2010.

Xu, X. D., Zhou, X. J., and Shi, X. H.: Spatial structure and scale feature of the atmospheric pollution source impact of city agglomeration, Science in China Series D - Earth Science 48 (Suppl. II), 1-24, 2005.

Zhao, C., Wang, Y., and Zeng, T.: East China Plains: A "Basin" of Ozone Pollution, Environ. Sci. Technol., 43(6), 1911-1915, 2009.

Zhang, Q., Streets, D. G., Carmichael, G. R., He, K. B., Huo, H., Kannari, A., Klimont, Z., Park, I. S., Reddy, S., Fu, J. S., Chen, D., Duan, L., Lei, Y., Wang, L. T., and Yao, Z. L.: Asian emissions in 2006 for the NASA INTEX-B mission, Atmos. Chem. Phys., 9, 5131-5153, doi:10.5194/acp-9-5131-2009, 2009.

Zhang, X., Cai, X. H., and Chai, F. H.: Structures and Characteristics of the Atmospheric Boundary Layer over Beijing Area in Autumn, Acta Scientiarum Naturalium Universitatis Pekinensis, 42(2), 220-225, 2006. 